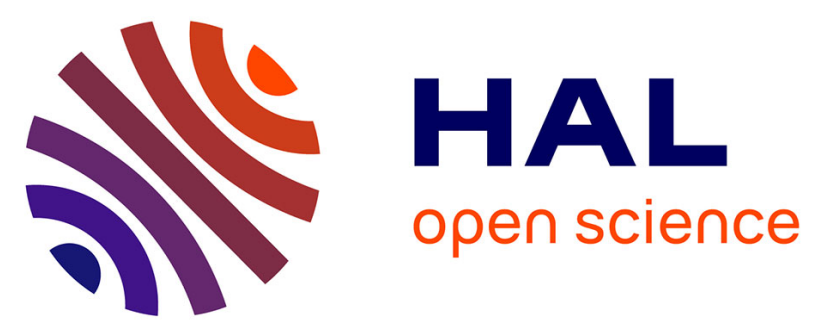

\title{
Genesis of the volcanic-related Be-U-Mo Baiyanghe deposit, West Junggar (NW China), constrained by mineralogical, trace element and $\mathrm{U}-\mathrm{Pb}$ isotope signatures of the primary $\mathrm{U}$ mineralisation
}

Christophe Bonnetti, Xiaodong Liu, Julien Mercadier, Michel Cuney, Bin Wu,

Guanglai Li

\section{To cite this version:}

Christophe Bonnetti, Xiaodong Liu, Julien Mercadier, Michel Cuney, Bin Wu, et al.. Genesis of the volcanic-related Be-U-Mo Baiyanghe deposit, West Junggar (NW China), constrained by mineralogical, trace element and U-Pb isotope signatures of the primary U mineralisation. Ore Geology Reviews, 2021, 128, pp.103921. 10.1016/j.oregeorev.2020.103921 . hal-03444655

\section{HAL Id: hal-03444655 \\ https://hal.science/hal-03444655}

Submitted on 24 Nov 2021

HAL is a multi-disciplinary open access archive for the deposit and dissemination of scientific research documents, whether they are published or not. The documents may come from teaching and research institutions in France or abroad, or from public or private research centers.
L'archive ouverte pluridisciplinaire HAL, est destinée au dépôt et à la diffusion de documents scientifiques de niveau recherche, publiés ou non, émanant des établissements d'enseignement et de recherche français ou étrangers, des laboratoires publics ou privés. 


\title{
Genesis of the volcanic-related Be-U-Mo Baiyanghe deposit, West Junggar (NW China), constrained by mineralogical, trace element and $\mathrm{U}$-Pb isotope signatures of the primary U mineralisation
}

\author{
Christophe Bonnetti ${ }^{\mathrm{a}^{*}}$, Xiaodong Liu ${ }^{\mathrm{a}, \mathrm{c}^{*}}$, Julien Mercadier ${ }^{\mathrm{b}}$, Michel Cuney ${ }^{\mathrm{b}}$, Bin $\mathrm{Wu}^{\mathrm{a}}$, Guanglai $\mathrm{Li}^{\mathrm{a}}$

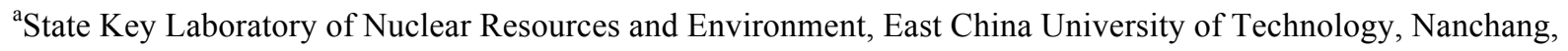 \\ Jiangxi 330013, China \\ ${ }^{\mathrm{b}}$ GeoRessources, CNRS, CREGU, Université de Lorraine, F-54000 Nancy, France \\ ${ }^{\mathrm{c} J i u j i a n g ~ U n i v e r s i t y, ~ J i u j i a n g, ~ J i n a g x i ~ 332005, ~ C h i n a ~}$
}

\begin{abstract}
The Volcanic-related Be-U-Mo Baiyanghe deposit is located in the Paleozoic Xuemisitan Volcanic Belt in West Junggar (NW China). It is the largest Be deposit in Asia which is dominantly hosted in late Devonian rhyolitic tuff and in the late Carboniferous Yangzhuang granite $(313 \pm 2 \mathrm{Ma})$ that were emplaced after the closure of the Junggar oceanic domain. The late Devonian rhyolitic tuff is a strongly fractionated peralkaline A1-type volcanic rock with a major magmatic enrichment in $\mathrm{Nb}, \mathrm{Y}, \mathrm{Th}, \mathrm{Be}$, Ta and $\mathrm{U}$. Highly fractionated REE patterns and significant concentrations of $\mathrm{Pb}, \mathrm{Nb}, \mathrm{Zr}, \mathrm{Y}$, Th and $\mathrm{Ta}$ in the primary $\mathrm{U}$ mineralisation identified these tuffs as the dominant $\mathrm{U}$ and probably Be source for Be-U ore genesis in West Junggar. The primary high $U$ concentrations $\left(6.5<\mathrm{U}_{\text {mean }}<15.0 \mathrm{ppm}\right)$ were released through volcanic glass devitrification and mobilised by oxidising fluids for the formation of hydrothermal mineralisation. The Yangzhuang granite is to the contrary a moderately fractionated moderate- to high-K calc-alkaline A2-type granite characterised by low magmatic $U$ and Be enrichment $\left(U_{\text {mean }}=2.9 \mathrm{ppm} ; \mathrm{Be}_{\text {mean }}=4.7 \mathrm{ppm}\right)$, and thus constituted a minor $U$ source for the mineralisation as demonstrated by $U$ release and remobilisation from metamict U-bearing accessory minerals.
\end{abstract}


In the Baiyanghe deposit, structurally-controlled primary $\mathrm{U}$ mineralisation was temporally constrained by an in situ $\mathrm{U}-\mathrm{Pb}$ isotopic minimum crystallisation age of $240 \pm 7 \mathrm{Ma}$ on pitchblende. This event represents the hydrothermal stage of $U$ mineralisation that occurred during the early Permian-middle Triassic post-accretion event in West Junggar and paragenetically postdates the $\mathrm{Be}$ ore stage (ca. 303-265 Ma). The hydrothermal U mineralisation is mainly characterised by $\mathrm{Pb}-\mathrm{Nb}-\mathrm{Ti}-\mathrm{Zr}-\mathrm{Mo}-\mathrm{rich}$ pitchblende veins associated with calcite and quartz, which crosscut Be-stage fluorite veins. During this episode of crustal extension, the Be-U-Mo ore therefore formed in a two-stage hydrothermal model within the same mineralising event: (i) oxidising meteoric and possibly basinal waters percolated downward into the basement through structures and mixed with $\mathrm{CO}_{2}$-bearing magmatic fluids derived from early generations of mafic dykes that intruded the host rocks in the Baiyanghe area. During the circulation of these thermal solutions along faults and fractured zones, $\mathrm{Be}$ was leached mainly from the Devonian rhyolitic tuff during hydrothermal alteration and dominantly transported as fluoride complexes in the fluids. These low-temperature (130$150^{\circ} \mathrm{C}$ ) ore solutions then reacted with Ca-rich minerals of the host rocks, which resulted in a $\mathrm{pH}$ increase that triggered fluorite precipitation in turn promoting $\mathrm{Be}$ deposition as bertrandite; and (ii) in a second stage, additional oxidising surface-derived fluids including meteoric waters and possibly basinal brines infiltrated the basement. $U$ was also leached mainly from the late Devonian rhyolitic tuff and likely transported as chlorine and/or uranyl carbonate complexes in the fluids. $\mathrm{U}$ precipitated as pitchblende due to $f \mathrm{O}_{2}$ decrease when these low-temperature $\left(120-125^{\circ} \mathrm{C}\right)$ oxidising U-bearing solutions encountered favourable reducing environments mainly represented by dolerite and diabase dykes crosscutting the host rocks and/or carbonaceous shales at the contact with the Devonian rhyolitic tuff. Pitchblende then locally experienced dyke-emplacement related post-ore hydrothermal potassic alteration characterised by abundant illite crystallisation, significant $\mathrm{Si}$ gain and in situ relative 
enrichment of $\mathrm{Nb}, \mathrm{Ti}, \mathrm{Th}$, and $\mathrm{Ta}$ due to strong $\mathrm{U}$ and $\mathrm{Pb}$ depletion. The primary $\mathrm{U}$ mineralisation was then largely oxidised into uranophane due to supergene alteration related to further meteoric water infiltration during late Mesozoic-Cenozoic crustal extension in West Junggar.

The characteristics of the volcanic-related hydrothermal Be-U mineralisation in the Baiyanghe deposit show key similarities with Streltsovka (U-Mo-F) and Spor Mountain (BeU) world-class districts, although Baiyanghe has much smaller resources than the ones in Streltsovka.

Keywords: West Junggar; Xuemisitan Volcanic Belt; volcanic-related hydrothermal uranium deposits; Baiyanghe deposit; Be-U-Mo mineralisation.

\section{Introduction}

The Baiyanghe Be-U-Mo deposit is located in the late Paleozoic Xuemisitan-Kulankazi island arc at the northwest margin of the Junggar plate, in northwest China (Fig. 1A; Li et al., 2015; Zhang et al., 2019). Although the U mineralisation was first discovered in the Baiyanghe deposit (> 2000t U at $0.05-0.2 \%$ U; IAEA, 2016), it actually represents the largest beryllium deposit (2.2 $\mathrm{M}$ tons of ore with grades ranging from $0.2 \%$ to $1.4 \%$ ) in Asia (Wang et al., 2012; Li et al., 2015).

The Be-U-Mo mineralisation in the Baiyanghe deposit is predominantly hosted in late Devonian felsic volcanic rocks of the Tarbagatay Group and in the late Carboniferous Yangzhuang granite porphyry (Fayek and Shabaga, 2011; Li et al., 2015; Shabaga et al., 2013; Zhang et al., 2019). Zou (2006) first compared this deposit with the Spor Mountain volcanic-tuff related Be-U deposit in the U.S.A that constitutes the world's most important resource of Be (Lindsey et al., 1973; Lindsey, 1977; Foley et al., 2012; Lederer et al., 2016), and suggested that the Baiyanghe Be-U-Mo deposit formed during the hydrothermal activity that post-dated the emplacement of the Yangzhuang granite porphyry (Fig. 1B). Ore bodies in 
the Baiyanghe deposit mainly occur as fracture fillings along contact zones between the Yangzhuang granite porphyry and the Devonian volcanic rocks. Based on their spatial distribution within the host rocks three types of ore were proposed, namely Be-type, U-type and Be-U-Mo type (Wang et al., 2012; Xiao et al., 2011; Xiu et al., 2011), the third type corresponding to the overlap of the first two. However, the genesis of the mineralisation including the spatial and temporal relations between $\mathrm{Be}, \mathrm{U}$ and $\mathrm{Mo}$, and the role of the Yangzhuang granite porphyry still remain unclear. While Shabaga et al. (2013) and Fayek and Shabaga (2011) characterised the Devonian rhyolite as the main host rock and source of U and Be for the Baiyanghe deposit, other studies (e.g. Li et al., 2015; Mao et al., 2014; Zhang et al., 2019, 2020) proposed the Yangzhuang granite porphyry as the predominant host rock and source of metals for the mineralisation. Moreover, the multiple generations of fluorite observed in the deposit (Li et al., 2015; Yi et al., 2016; Zhang et al., 2019) as well as the detailed petrographic and geochemical study on the alteration minerals presented in Zhang et al. (2019), were taken as major lines of evidence to support a hydrothermal-related metallogenic model characterising multi-stage Be-U mineralisation in the Baiyanghe deposit. Microthermometry of fluid inclusions from fluorite indicated that $\mathrm{Be}$ and $\mathrm{U}$ minerals precipitated from low-temperature $\left(120-150{ }^{\circ} \mathrm{C}\right)$ and low-to moderate-salinity fluids $(4.7 \%<$ $\mathrm{NaCl}$ eq. $<19.7 \%$ ) (Fayek and Shabaga, 2011; Li et al., 2015; Mao et al., 2013; Yang et al., 2014; Yi et al., 2016). Furthermore, Li et al. (2015) proposed that the ore-forming solutions originated from the mixing of magmatic and meteoric fluids based on $\mathrm{O}$ and $\mathrm{H}$ isotopic signatures of hydrothermal muscovite. However, whereas the dark purple fluorite (fluorite (2) in Li et al., 2015; Zhang et al., 2019) co-precipitated with the principal Be mineral (bertrandite, $\left(\mathrm{Be}_{4} \mathrm{Si}_{2} \mathrm{O}_{7}(\mathrm{OH})_{2}\right)$ ), the textural relations between pitchblende and the other hydrothermal minerals described by Yi et al. (2016) and Zhang et al. (2019) do not allow for clear determination of paragenetic succession. Finally, the timing between the Be and primary 
$\mathrm{U}$ mineralisation is still under debate. Li et al. (2015) proposed that Be and $\mathrm{U}$ were deposited together with coeval hydrothermal muscovite dated by Ar-Ar method at $303 \pm 2 \mathrm{Ma}$. On the contrary, Sm-Nd dating performed by Yi et al. (2016) on ore-stage fluorite gave an age of $265 \pm 33 \mathrm{Ma}$ for the Be mineralisation, and U-Pb TIMS dating on pitchblende-bearing samples yielded a series of dates at $238 \pm 3 \mathrm{Ma}, 224 \pm 3 \mathrm{Ma}, 198 \pm 3 \mathrm{Ma}, 98 \pm 1 \mathrm{Ma}$ and $30 \pm 1 \mathrm{Ma}$, hence suggesting that Be and $\mathrm{U}$ mineralisation could have occurred later than proposed in Li et al. (2015). Most recent works (e.g. Xu et al., 2017; Zhang et al., 2019) also proposed that the primary $\mathrm{U}$ mineralisation was closely related to the multiple stages of mafic dyke intrusions emplaced during the early Permian-late Triassic post-orogenic event in West Junggar.

In order to address the above issues, the present study aims to characterise the mineralogical, chemical and isotopic signatures of the primary $U$ mineralisation from the Baiyanghe deposit through detailed petrographic and mineralogical studies and the measurements of the trace element concentrations by LA-ICP-MS and U-Pb isotopes by SIMS in pitchblende. Ultimately, the new petrographic-mineralogical observations and analytical data provided by this paper will allow proposing a unified metallogenic model for the volcanic-related hydrothermal Baiyanghe deposit based on the spatial-temporal relations between $\mathrm{Be}$ and $\mathrm{U}$ in the system.

\section{Geological setting}

\subsection{Regional geology}

The Baiyanghe deposit is located in West Junggar region, situated on the southern part of the Altai Orogen (Mao et al., 2014). The area is characterised by three magmatic belts (Li et al., 2015) including: (i) the EW-trending Xuemisitan Volcanic Belt and (ii) the EW-trending Saur Volcanic Belt located in northern West Junggar (Zhang et al., 2019; Zhong et al., 2017), and (iii) the NE-trending alkali-feldspar granitic belt in southern West Junggar (Chen et al., 2010) (Fig. 1). 
In northern West Junggar, the Saur Volcanic Belt on the north, mainly composed of calcalkaline basalts and basaltic andesites, is the product of southward subduction of the IrtyshZaysan oceanic lithosphere during the Devonian-early Carboniferous (Didenko and Morozov, 1999; Vladimirov et al., 2008). The Xuemisitan belt on the south is dominated by a suite of Devonian intermediate to felsic volcanic and intrusive rocks, and minor amounts of late Carboniferous-middle Permian granite, granite porphyry, and diorite (Fig. 1; Li et al., 2015). It resulted from southward subduction of the Junggar oceanic crust during the late Silurianearly Devonian (Li et al., 2015; Mao et al., 2014; Shen et al., 2012; Zhao and He, 2013). The closure of the oceanic basin between the Xuemisitan and Saur volcanic belts took place before the late Devonian ( 380 Ma, Filippova et al., 2001), whereas the Irtysh-Zaysan oceanic basin closed in the late Carboniferous (Chen et al., 2010; Han et al., 2010; Kuibida et al., 2009). Ages of the granite batholiths and their coeval mafic intrusions in the region indicate that voluminous magmatism took place during the late Carboniferous to early Permian (Geng et al., 2009). Lithofacies paleogeographical studies and paleomagnetic research revealed that a remnant oceanic basin still existed in the northern West Junggar region until 300 Ma ago (Choulet et al., 2011; Wang, 2006; Wang et al., 2007), which strongly argues in favour of an ocean ridge subduction model to interpret the extensive late Carboniferous magmatism in West Junggar (Geng et al., 2011, 2009; Tang et al., 2010a, 2010b, 2009; Yang et al., 2012; Yin et al., 2011, 2010). The northern West Junggar region then entered in a post-orogenic stage (Choulet et al., 2012, 2011) associated with intraplate magmatism characterised by multiple events of dyke intrusions during the early Permian-middle Triassic (Miao et al., 2019; Yi et al., 2014), including diorite porphyry (290 $\pm 18 \mathrm{Ma}, 222 \pm 18 \mathrm{Ma})$, dolerite $(277 \pm 6$ Ma, 272 $\pm 4 \mathrm{Ma})$, diabase (255 Ma), and alaskite (255 $\pm 2 \mathrm{Ma}, 246 \pm 1 \mathrm{Ma})$.

\subsection{Geology of the Baiyanghe Be-U-Mo deposit}

The Baiyanghe Be-U-Mo deposit is located on the northwestern margin of the Xuemisitan 
Volcanic Belt (Fig. 1A). In the Baiyanghe area, stratigraphic sequences include the late Devonian Tarbagatay Group of intermediate to felsic volcanic and pyroclastic rocks, the early Carboniferous Hebukehe Group of shale, limestone, siliceous shale, sandstone and conglomerate, and the early Carboniferous Heishantou Group of mafic to intermediate volcanic and pyroclastic rocks (Mao et al., 2013; Wang et al., 2012; Zhang and Zhang, 2014). These volcano-sedimentary units were then intruded by the late Carboniferous Yangzhuang granite porphyry and a series of dykes emplaced during the early Permian-late Triassic (Figs. 1B and 1C; Li et al., 2015; Miao et al., 2019; Yi et al., 2014; Zhang et al., 2019). The Be-UMo mineralisation is mainly hosted within the Yangzhuang granite porphyry and the late Devonian rhyolite and rhyolitic tuff of the Tarbagatay Group (Figs. 1 and 2; Li et al., 2015; Shabaga et al., 2013; Xu et al., 2017; Zhang et al., 2019). The Yangzhuang granite porphyry intruded from the east of the Baiyanghe area and along the EW-trending Yangzhuang Fault in the south, at a $45-75^{\circ}$ north-dipping contact with early Carboniferous rocks. In the north, the Yangzhuang granite displays $\mathrm{a} \sim 30^{\circ}$ south-dipping curved-tectonic contact (synform) with the Devonian volcanic rocks (Fig. 1C; Li et al., 2015; Zhang et al., 2019).

The Yangzhuang granite porphyry exhibits a porphyritic texture with quartz and Kfeldspar phenocrysts. However, the highly fractured phenocrysts supported by a microgranular matrix rather characterise a trachytic texture belonging to a subvolcanic rock facies (Fig. 2A; $\mathrm{Xu}$ et al., 2017). The main mineral assemblage is composed of quartz, $\mathrm{K}-$ feldspar, plagioclase, and mica (Li et al., 2015; Zhang et al., 2019). Zircon, (U)-thorite, columbite-(Mn), and REE-fluoro-carbonate are the dominant accessory minerals (Zhang et al., 2020). Zircon U-Pb dating of the granite porphyry yielded an emplacement age of $313 \pm 2$ Ma (Zhang and Zhang, 2014). It was previously characterised as a metaluminous to weakly peraluminous fractionated A1-type granite (according to Eby, 1992), associated with very high Nb (84-121 ppm) and Ta (7.6-9.4 ppm) concentrations (Mao et al., 2014; Zhang et al., 
2019), which are nearly ten times higher than the coeval granite of A2-type affinity in this region. The Devonian rhyolite and rhyolitic tuff (Figs. 2B and 2C) were characterised by Fayek and Shabaga (2011) and Shabaga et al. $(2015,2013)$ as a peralkaline to weakly peraluminous strongly fractionated $\mathrm{Nb}$-rich rhyolite $\left(\mathrm{Nb}_{\text {mean }} 124 \mathrm{ppm}\right)$. They are mainly composed of quartz, K-feldspar, volcanic glass and biotite with accessory minerals including topaz and tourmaline.

The mineralisation at the Baiyanghe deposit is predominantly hosted in the Devonian rhyolite and in minor proportion in the Yangzhuang granite porphyry (Figs. 1C and 2D-2G; Fayek and Shabaga, 2011; Li et al., 2015; Shabaga et al., 2013; Zhang et al., 2019). Be-U-Mo ore bodies mainly occur in fractures along contact zones between the Yangzhuang granite porphyry and Devonian volcano-sedimentary rocks (Figs. 1C, and 2E-F). Small amounts of the mineralisation also occur along structures inside the granite itself (Figs. 1C and 2D). Three types of ore were identified in the deposit, namely Be type, $U$ type, and U-Be-Mo type (Wang et al., 2012; Xiao et al., 2011; Xiu et al., 2011). These three types of ore occur either separately or show a crosscutting relationship (Fig. 1C). The Be-U-Mo mineralisation is also spatially associated with the intrusion of NW-trending diabase dykes (Li et al., 2015; Xu et al., 2017; Zhang et al., 2019), which vary in width from a few centimetres to several meters within the Yangzhuang granite porphyry. Be-U grades are lower in the western section of the Yangzhuang granite, where the diabase and diorite dykes are well developed, and higher in the eastern section, where the dykes are scarcer (Fig. 1B; Li et al., 2015; Zhang et al., 2019). Three Be-U-Mo ore bodies have been identified to date. The No. 1 ore body is the largest and contains $90 \%$ of the $\mathrm{BeO}$ reserves (Fig. 1C). The No. 1 ore body is stratiform in shape and occurs at the contact zone between the Yangzhuang granite and Devonian rhyolite. It extends over $600 \mathrm{~m}$ long by up to $300 \mathrm{~m}$ wide, and has a thickness ranging from $1.5 \mathrm{~m}$ to $20 \mathrm{~m}$ with an average of $\sim 5 \mathrm{~m}$. The predominant primary $\mathrm{U}$ mineral is pitchblende, which is largely 
overprinted by the secondary U mineral uranophane (Li et al., 2015; Shabaga et al., 2013; Zhang et al., 2019). U-Pb isotopic TIMS dating on pitchblende-bearing samples yielded a series of dates at $238 \pm 3 \mathrm{Ma}, 224 \pm 3 \mathrm{Ma}, 198 \pm 3 \mathrm{Ma}, 98 \pm 1 \mathrm{Ma}$ and $30 \pm 1 \mathrm{Ma}$ (Yi et al., 2016). $\mathrm{U}-\mathrm{Pb}$ SIMS dating performed on uranophane yielded dates within the range 130-20 Ma (Fayek and Shabaga, 2011; Shabaga et al., 2015). The principal Be mineral is bertrandite, which mainly occurs as fine planar and $20-300-\mu$ m-long prismatic crystals within the dark purple fluorite veins (Li et al., 2015; Shabaga et al., 2013; Zhang et al., 2019). Ore-stage fluorite gave $\mathrm{Sm}-\mathrm{Nd}$ isotopic age of $265 \pm 33 \mathrm{Ma}$ (Yi et al., 2016). Mo mineralisation primarily occurred as molybdenite, which was oxidised into supergene Mo-oxide (e.g. ilsemannite; Li et al., 2015).

The pre-Be-ore alteration minerals are albite, chlorite, quartz, and colourless and green fluorite (F11) (Zhang et al., 2019). The colourless and green fluorite is generally not directly associated with Be-U mineralisation. The original K-feldspar was partly replaced by sericite and albite. Secondary quartz that coexists with chlorite commonly occurs as veins in the host rocks. Calcite surrounded by chlorite can also be found. The Be-ore-stage hydrothermal alteration is characterised by several generations of fluorite, quartz, illite/muscovite, kaolinite, chlorite and calcite (Zhang et al., 2019). Fluorite that formed during this stage displays light to dark purple colours. The earlier dark purple fluorite (F12) is cut by the later light purple fluorite (F13) (Fig. 2H). Bertrandite is closely associated with the fluorite formed during this stage but no clear petrographic relations with pitchblende have been presented to date. The alteration minerals in the post-ore stage mainly include calcite, quartz and colourless to light purple fluorite (F14). Uranophane partly to totally replaces pitchblende in fractures and is associated with Pb-and Mn-oxides (Shabaga et al., 2013; Zhang et al., 2019).

\section{Materials and methods}

\subsection{Sampling}


Twenty-five samples including sixteen samples of the main host rocks, seven mineralised samples and two mafic dyke samples were collected from outcrops and exploration drill holes in the area of the Baiyanghe deposit. The host rock samples include nine samples of late Devonian rhyolitic tuff and seven samples of the late Carboniferous Yangzhuang granite porphyry. Two high-grade mineralised samples $(0.1-1 \% \mathrm{U})$ from the $\mathrm{U}$ ore and containing primary $\mathrm{U}$ mineralisation (pitchblende) were collected in exploration drill holes ZK5434 and ZK5828 (Fig. 1B) at depths $358.3 \mathrm{~m}$ and $285.2 \mathrm{~m}$, respectively. These two samples were studied in details to constrain the U ore genesis in the Baiyanghe deposit.

\subsection{Whole rock geochemistry}

Whole-rock geochemistry was performed by inductively coupled plasma mass spectrometry/atomic emission spectrometry (ICP-AES) and X-ray fluorescence spectrometry (XRF) at the Hubei Province Geological Lab Testing Center in Wuhan (China).

\subsection{Microscopy and mineral analysis by EPMA}

The petrographic/mineralogical study was carried out at the State Key Laboratory of Nuclear Resources and Environment of the East China University of Technology (China) using: (i) optical microscope (transmitted and reflected lights), (ii) a FEI-Nova Nano-SEM 450 scanning electron microscope (SEM), and (iii) a JEOL JXA 8100 electron probe microanalyser (EPMA). EPMA analytical conditions were $15 \mathrm{kV}$ accelerating voltage, $20 \mathrm{nA}$ beam current with a $5 \mu \mathrm{m}$ beam diameter for the composition analysis of $U$ minerals (pitchblende and uranophane). X-ray elemental mapping was carried out on two pitchblende veins using the same conditions as for in situ measurements. The step size was $1 \mu \mathrm{m}$ with a spot size of about $1 \mu \mathrm{m}$. X-ray were collected with a dwell time of $40 \mathrm{~ms}$ per pixel.

\subsection{Trace element measurements by LA-ICP-MS}

The measurement of trace element concentrations in pitchblende was performed by laser ablation inductively coupled plasma mass spectrometry (LA-ICPMS; AGILENT 7500) at the 
GeoRessources Laboratory of the Université de Lorraine-CNRS in Nancy (France). The detailed methodology that was followed for LA-ICP-MS measurements is presented in Bonnetti et al. (2020, 2018a). For each analysis performed on pitchblende, a $32 \mu \mathrm{m}$ or $16 \mu \mathrm{m}$ spot size has been used depending on the size of the mineral. Rare earth elements (REE: La, $\mathrm{Ce}, \mathrm{Pr}, \mathrm{Nd}, \mathrm{Sm}, \mathrm{Eu}, \mathrm{Gd}, \mathrm{Tb}, \mathrm{Dy}, \mathrm{Ho}, \mathrm{Er}, \mathrm{Tm}, \mathrm{Yb}, \mathrm{Lu})$ along with ten trace elements (Zr, Ba, Sr, W, Nb, Ta, Y, Mo, Th and Ti) were analysed. A dwell time of $10 \mathrm{~ms}$ was used for each measured isotope, except for U (5 ms). The certified glass standards NIST610 and 612 (Pearce et al., 1997) were used as reference material for the analyses of trace elements in pitchblende using $\mathrm{U}$ content measured by EPMA as internal standard, following the protocol developed by Lach et al. (2013). Then, data were processed using the Iolite program (Paton et al., 2011) in order to convert raw counts for every measured trace element into concentration (in ppm). U was used as internal standard, based on concentration established for each analysed zone by EPMA. The selected $U$ concentrations varied from 60 to $70 \mathrm{wt} \% \mathrm{U}$, depending on the type of $U$ mineralisation and degree of alteration. The relative error on concentrations is generally around $5 \%$.

\subsection{U-Pb isotopes dating by SIMS}

$\mathrm{U}-\mathrm{Pb}$ isotopic compositions of pitchblende were determined using a CAMECA IMS 1280HR ion microprobe at CRPG-CNRS (Nancy, France). The $\mathrm{O}^{-}$primary ion beam was accelerated at $13 \mathrm{kV}$, with an intensity ranging between 3.5 and $5 \mathrm{nA}$. The spot size on pitchblende was $\sim 15 \mu \mathrm{m}$. Positive secondary ions were extracted with a $10 \mathrm{kV}$ potential, and the spectrometer slits were set for a mass resolving power of $\sim 6,000$ to separate isobaric interferences of REE dioxides from $\mathrm{Pb}$. Ions were measured by peak jumping in monocollection mode using the axial Faraday cup (FC) for ${ }^{238} \mathrm{U}$ and ${ }^{238} \mathrm{UO}$ and the axial electron multiplier (EM) for ${ }^{204} \mathrm{~Pb},{ }^{206} \mathrm{~Pb},{ }^{207} \mathrm{~Pb},{ }^{208} \mathrm{~Pb}$ and ${ }^{248} \mathrm{ThO}$. Each analysis consisted of 8 successive cycles. Each cycle began with measurement of the mass 203.5 and 203.6 for 
backgrounds of the FC and the EM respectively, followed by ${ }^{204} \mathrm{~Pb},{ }^{206} \mathrm{~Pb},{ }^{207} \mathrm{~Pb},{ }^{208} \mathrm{~Pb},{ }^{238} \mathrm{U}$, ${ }^{248} \mathrm{ThO}$ and ${ }^{238} \mathrm{UO}$, with acquisition times of $4,4,10,6,20,4,4,3$, and $3 \mathrm{~s}$, respectively (waiting time of $1 \mathrm{~s}$ ). The relative sensitivity factor between $\mathrm{Pb}$ and $\mathrm{U}$ used for unknown samples was determined from an empirical linear relationship defined between $\mathrm{UO}^{+} / \mathrm{U}^{+}$and $\mathrm{Pb}+/ \mathrm{U}^{+}$(Compston et al., 1984; Deloule et al., 2002) from all the measurements performed on the reference uraninite (Zambia, concordant age of $540 \pm 4$ Ma; Cathelineau et al., 1990). The error on the calibration curve for the reference material is reported in the error given for each analysis of unknown uranium oxide. Internal precision obtained on Zambia uraninite during the SIMS analytical session was $0.1 \%$ and $0.01 \%$ for ${ }^{206} \mathrm{~Pb} /{ }^{238} \mathrm{U}$ and ${ }^{207} \mathrm{~Pb} /{ }^{206} \mathrm{~Pb}$ ratios respectively. $\mathrm{A}^{238} \mathrm{U} /{ }^{235} \mathrm{U}$ ratio of 137.88 was used to calculate the ${ }^{207} \mathrm{~Pb} /{ }^{235} \mathrm{U}$ ratios based on the measured ${ }^{206} \mathrm{~Pb} /{ }^{238} \mathrm{U}$ and ${ }^{207} \mathrm{~Pb} /{ }^{206} \mathrm{~Pb}$ ratios. Due to the common $\mathrm{Pb}$-rich character of the $\mathrm{U}$ oxides $\left(0.0156>^{204} \mathrm{~Pb} /{ }^{206} \mathrm{~Pb}>0.0146\right)$, a common lead correction based on the measured ${ }^{204} \mathrm{~Pb}$ content and the $\mathrm{Pb}$ isotopic composition calculated using the model of Stacey and Kramers (1975) at the estimated age of the U oxide was applied to the analyses. Initial data treatment, standardisation against Zambia uraninite, calculation of $\mathrm{U} / \mathrm{Pb}$ and $\mathrm{Pb} / \mathrm{Pb}$ ratios and related ages, and calculation of error (1 sigma) were done using an in-house Excel spreadsheet at CRPG (Table G). Data implementation in Wetherwill and Tera-Wasserburg diagrams were done using ISOPLOT flowsheet (Ludwig, 1999). In this respect, an identical correlation error of 0.8 between ${ }^{206} \mathrm{~Pb} /{ }^{238} \mathrm{U}$ and ${ }^{207} \mathrm{~Pb} /{ }^{235} \mathrm{U}$ ratios was used (Table G). For more details about the analytical protocol, see Martz et al. (2019).

\section{Results}

\subsection{Typology of the host rocks}

The whole rock geochemical features of the late Devonian Rhyolitic tuff and late Carboniferous Yanghuang granite porphyry are presented in Figure 3. The data plotted aim to determine: (i) the typology of these host rocks, (ii) magmatic vs hydrothermal fractionation 
trends and (iii) their possible role as a metal source for the mineralisation. The whole-rock geochemical data including major elements, rare earth elements (REE) and trace elements are respectively presented in Tables A, B and C.

\subsubsection{Late Devonian rhyolitic tuff}

Late Devonian rhyolitic tuff represents the main host rock of the Baiyanghe deposit (Fig. 2). This volcanic rock is metaluminous to slightly peraluminous $(0.83<\mathrm{A} / \mathrm{CNK}<1.23$, Fig. $3 \mathrm{~A} ;-48<\mathrm{A}<44$, Fig. 3B) and characterised by very low contents of ferro-magnesian minerals $(\mathrm{B}<16$; Fig. 3B). It is rich in quartz $(\mathrm{Q}>163$; Fig. $3 \mathrm{C})$ and has a significant plagioclase proportion $(-140<\mathrm{P}<-53$; Fig. $3 \mathrm{C})$. Nevertheless, some low $\mathrm{P}$ values may also be attributed to the presence of carbonate in altered samples (e.g., sample BYH-06 with 1.61 $\mathrm{wt} \% \mathrm{CaO}$ and $\mathrm{P}=-110$; Table $\mathrm{A}$ ). It shows moderate to high $\mathrm{U}$ contents ranging from 3.1 to $12.3 \mathrm{ppm}\left(\mathrm{U}_{\text {mean }}=15 \mathrm{ppm}\right.$ in Fayek and Shabaga, 2011), and low to high $\mathrm{Th} / \mathrm{U}$ ratios $(2.8$ to 11.0; Table C), which is characteristic of a good $\mathrm{U}$ source for the mineralisation. Values of Th/U >> 4 (e.g. 11.0 in sample BYH-06; Table C) are indicative of U leaching (Fig. 3D). The rhyolite has low to moderate $\mathrm{K}_{2} \mathrm{O}$ contents $(3.33-4.10 \mathrm{wt} \%)$ and one anomalously low value at $2.74 \mathrm{wt} \%$ that is attributed to albitisation (5.99 $\mathrm{wt} \% \mathrm{Na}_{2} \mathrm{O}$ in sample BYH-07; Table A), also associated with the lowest concentrations in $\mathrm{Nb}$, Ta and $\mathrm{Th}$ (Table $\mathrm{C}$ ). The rhyolite also shows a very high degree of fractionation characterised by REE patterns with a pronounced negative Eu anomaly and a "gull-winged" shape (Fig. 3F), and by very high $\mathrm{Nb}$ content (up to 117.0 ppm; Fig. 3E; Table C) and relatively high concentration in Y (up to $51.8 \mathrm{ppm}$ ) and Th (up to $39.1 \mathrm{ppm}$ ). It is also significantly enriched in other incompatible elements like $\mathrm{Rb}$ and Ta, and strongly depleted in $\mathrm{Ba}$ (Fig. 3E), relative to the composition of the upper continental crust. In the $\mathrm{A} / \mathrm{NK} v s \mathrm{~A} / \mathrm{CNK}$ diagram (Fig. 3A) the composition of the rhyolitic tuff is very close to the origin. A slight alteration (i.e. incipient sericitisation of plagioclase) is sufficient to shift the composition from the peralkaline field to midly peraluminous to metaluminous 
compositions. Hence, we suggest that the initial composition of the rhyolitic tuff magma was midly peralkaline (A1-type according to Eby, 1992; Fig. A) as further supported by its very high $\mathrm{Fe} / \mathrm{Mg}$ and $\mathrm{Na} / \mathrm{K}$ ratios, low $\mathrm{Ca}$, Ti and $\mathrm{P}$ contents, high to very high concentrations of $\mathrm{Nb}$, Ta, Th, Y, and U, and the REE "gull-winged" pattern. These tuffs are also relatively enriched in Be with values up to $10 \mathrm{ppm}$ compared to an average biotite granite (5 ppm; Foley et al., 2017).

\subsubsection{Late Carboniferous Yangzhuang granite porphyry}

The Yangzhuang granite porphyry is the second main host rock of the mineralisation in the Baiyanghe deposit (Fig. 2). This granite is weakly to moderately peraluminous $(1.02<$ A/CNK $<1.15$, Fig. 3A; $6<\mathrm{A}<35$, Fig. 3B). It shows moderate to high quartz contents (117 $<$ Q $<190$; Fig. 3C), low contents of ferro-magnesian minerals (B $<56$; Fig. 3B), and variable proportions of K-feldspar relatively to plagioclase $(-120<\mathrm{P}<25$; Fig. 3C). The Yangzhuang granite has low $U$ contents ranging from 2.3 to $4.3 \mathrm{ppm}$ (mean $U$ content $=2.9 \mathrm{ppm}$ ), and $\mathrm{Th} / \mathrm{U}$ ratios around the average value in the continental crust (2.4 to 6.1 ; Table C; Fig. 3D), hence indicating that this granite likely represents a minor $\mathrm{U}$ source for the mineralisation. Be contents $($ mean $=4.7 \mathrm{ppm})$ are similar to the average concentrations in biotite granite, suggesting that the Yangzhuang granite may also represent a relatively minor source of Be for the mineralisation. Compared with the Devonian rhyolite, the granite porphyry is less fractionated as indicated by its REE patterns with weaker negative Eu anomalies (Fig. 3F), and lower concentrations in Th (10.4-14.1 ppm) and Ta (2.4-3.2 ppm), although Y (up to $57.5 \mathrm{ppm}$ ) and $\mathrm{Nb}$ (up to $46.8 \mathrm{ppm}$ ) contents remain relatively high (Table $\mathrm{C}$ ). The variable moderate to high $\mathrm{K}_{2} \mathrm{O}$ contents $(3.44-6.11 \mathrm{wt} \%)$ and the positive evolution trend of the Q-P parameters (Fig. 3C) define a moderate- to high-K calc-alkaline association and characterise the Yangzhuang granite as a moderately fractionated A2-type granite (according to Eby, 1992; Fig. A). 


\subsection{Petrography and mineral assemblage of the uranium mineralisation}

In the Baiyanghe deposit, two distinct stages of $U$ mineralisation were characterised from our sampling based on the predominant $U$ mineral, their respective mineral assemblage and textural relations (Figs. 2 and 4): (i) an early hydrothermal pitchblende-dominated stage mainly associated with illite, quartz and calcite; and (ii) a late supergene alteration uranophane-dominated stage comprising hexavalent $U$ silicate, quartz, calcite, barite and $\mathrm{Pb} / \mathrm{Ti}$-oxide. Both $\mathrm{U}$ mineralisation stages are represented by different generations of veins that postdate Be ore-stage fluorite veins (Fig. 4).

\subsubsection{Primary uranium mineralisation}

The hydrothermal stage is characterised by pitchblende as the predominant $\mathrm{U}$ mineral, which represents the primary $U$ mineralisation. It occurs as 0.01 -to $2 \mathrm{~cm}$-thick veins (Fig. 4) within fractured zones of the host rocks. Pitchblende displays colloform to massive textures and shows centripetal evolution of the crystal growth in veins. In sample 5828, colloform pitchblende displays a succession of five major bands of hydrothermal growth (Figs. 4A and 4B), whereas in sample 5434, pitchblende is alternating with micrometre-thick layers of microcrystalline quartz (Figs. 4D-4F). Pitchblende is subsequently fractured (Fig. 4A) and mainly associated with illite, quartz and calcite. Illite is a major alteration mineral occurring in the matrix of mineralised host rocks or in fractures crosscutting pitchblende (Fig. 4). In sample 5828, edges of the pitchblende vein (Figs. 4A and 4B) show alteration features mainly characterised by $\mathrm{Nb} / \mathrm{Ti}$-rich altered pitchblende domains intimately associated with illite and other phyllosilicates. Calcite and quartz occur as cement in veins together with pitchblende (Figs. 4E and 4F). At the thin section scale, pitchblende veins crosscut early muscovite and dark purple fluorite veins (Figs. 4C-4G) that are associated with bertrandite and therefore, postdate the Be mineralisation. Fluorite is intensively fractured and brecciated by later 
generations of pitchblende veins, which also replace an early generation of illite (Figs. 4D and 4E).

\subsubsection{Secondary uranium mineralisation}

The supergene stage is characterised by uranophane as the principal $U$ mineral also associated with minor hexavalent $\mathrm{U}$ silicate (e.g., uranosilite), which represents the secondary $\mathrm{U}$ mineralisation. Uranophane either occurs in re-opened pre-existing pitchblende veins as 10 to $100 \mu \mathrm{m}$ crystal aggregates replacing pitchblende (Figs. 4D and 4F), or in a newly formed set of veins crosscutting hydrothermal fluorite, illite/muscovite, and pitchblende veins (Fig. 4C). Hexavalent U silicate mainly occurs in alteration of pitchblende or was co-precipitated with uranophane in veins (Fig. 4D). Uranophane is also associated with a series of alteration and gangue minerals mainly including quartz, calcite, barite and $\mathrm{Pb}$ /Ti-oxide. Microcrystalline quartz and calcite occur as cement in uranophane veins (Figs. 4C and 4F), and barite and $\mathrm{Pb}$ /Ti-oxide have been observed replacing of pitchblende (Fig. 4G).

\subsection{Composition of the primary uranium minerals}

In sample 5828, among the five growth bands of hydrothermal pitchblende, the latest band (V) shows a reasonably preserved chemical composition (Figs. 5 and 7; Table 1; Table D) characterised by very high $\mathrm{UO}_{2}$ (mean $=78.08 \mathrm{wt} \%$, Figs. 7A-B) and high $\mathrm{PbO}$ contents $($ mean $=7.76 \mathrm{wt} \%$, Fig. $7 \mathrm{~A})$, and homogeneous and relatively low concentrations in $\mathrm{Nb}$ $\left(\right.$ mean $=1.91 \mathrm{wt}^{\circ} \% \mathrm{Nb}_{2} \mathrm{O}_{5}$, Fig. $\left.7 \mathrm{E}\right), \mathrm{Ti}\left(\right.$ mean $=0.81 \mathrm{wt} \% \mathrm{TiO}_{2}$, Fig. $\left.7 \mathrm{~F}\right), \mathrm{W}($ mean $=0.74$ $\left.\mathrm{wt} \% \mathrm{WO}_{3}\right)$ and $\mathrm{Zr}\left(\right.$ mean $\left.=0.48 \mathrm{wt} \% \mathrm{ZrO}_{2}\right)$. Relatively homogeneous $\mathrm{Ca}$ contents (mean $=$ $2.26 \mathrm{wt} \% \mathrm{CaO}$, Fig. 7C) suggest that calcium was most likely incorporated during crystallisation and very low $\mathrm{Si}$ concentrations (mean $=0.32 \mathrm{wt} \% \mathrm{SiO}_{2}$, Fig. 7D) shows evidence for a low degree of post-crystallisation alteration (Fig. 5). In comparison, pitchblende (I) to (IV) (Fig. 4A) have more variable compositions characterised by lower $\mathrm{UO}_{2}$ (64.92-76.12 wt\%, Fig. 7A) and $\mathrm{PbO}(4.44-9.06$ wt\%, Figs. 7A, 7C-D) contents, and higher 
concentrations in $\mathrm{Nb}\left(2.76-9.14 \mathrm{wt} \% \mathrm{Nb}_{2} \mathrm{O}_{5}\right.$, Fig. 7E) and $\mathrm{Ti}\left(0.36-2.31 \mathrm{wt} \% \mathrm{TiO}_{2}\right.$, Fig. 7F). Individually, pitchblende (I) to (IV) have relatively homogeneous $\mathrm{CaO}$ contents (Fig. 7C), indicating that calcium was most probably incorporated during crystallisation, although a minor part could be related to post-crystallisation alteration. Low to high $\mathrm{SiO}_{2}$ concentrations (0.27-4.97 wt \%, Fig. 7C) indicate heterogenous degrees of post-crystallisation alteration. An altered pitchblende domain (Figs. 4A-B) is characterised by high to very high concentrations in $\mathrm{Nb}$ (up to $20.22 \mathrm{wt} \% \mathrm{Nb}_{2} \mathrm{O}_{5}$, Fig. 7E), $\mathrm{Ti}$ (up to $7.19 \mathrm{wt} \% \mathrm{TiO}_{2}$, Fig. 7F), and $\mathrm{Si}$ (up to $22.21 \mathrm{wt} \% \mathrm{SiO}_{2}$, Figs. 7B and 7D-F).

In sample 5434, pitchblende is characterised by very high $\mathrm{UO}_{2}$ (mean $=76.30 \mathrm{wt} \%$, Figs. 7A-B) and relatively high $\mathrm{PbO}($ mean $=4.45 \mathrm{wt} \%$, Fig. 7A) contents, and variable low to very low concentrations in $\mathrm{Nb}\left(<\mathrm{LOD}-2.77 \mathrm{wt} \% \mathrm{Nb}_{2} \mathrm{O}_{5}\right.$, Fig. 7E), $\mathrm{Zr}\left(<\mathrm{LOD}-1.06 \mathrm{wt} \% \mathrm{ZrO}_{2}\right)$, W $\left(<\mathrm{LOD}-0.69 \mathrm{wt} \% \mathrm{WO}_{3}\right)$ and $\mathrm{Ti}\left(<\mathrm{LOD}-0.42 \mathrm{wt} \% \mathrm{TiO}_{2}\right.$, Fig. $\left.7 \mathrm{~F}\right)$. It also has relatively homogeneous high $\mathrm{Ca}($ mean $=7.17 \mathrm{wt} \% \mathrm{CaO}$, Fig. $7 \mathrm{C})$ and $\mathrm{Si}\left(\right.$ mean $=6.01 \mathrm{wt} \% \mathrm{SiO}_{2}$, Fig. 7D) contents. Here, the relatively high $\mathrm{SiO}_{2}$ concentrations measured by the EPMA are due to contamination by the micro-rims of microcrystalline quartz alternating with pitchblende in veins (Figs. 4F and 6). Otherwise, pitchblende shows low degrees of post-crystallisation alteration as indicated by very low $\mathrm{Si}$ contents $\left(<<1.00 \mathrm{wt} \% \mathrm{SiO}_{2}\right.$, Figs. 7B and 7D-F) measured on quartz-free zones (Table 1; Table D).

\subsection{Trace element concentrations in pitchblende}

Chondrite-normalised REE spectra of pitchblende from samples 5434 and 5828 in the Baiyanghe deposit (Figs. 8A-B, Table E) have a typical "gull-winged" pattern characterised by well-pronounced negative $\mathrm{Eu}$ anomalies and high enrichments in HREE relatively to LREE. In sample 5828, variably altered pitchblende (I) to (IV) and $\mathrm{Nb} / \mathrm{Ti}$-rich altered pitchblende show higher LREE enrichment and slight HREE depletion compared with nonaltered pitchblende (V) (Fig. 8B). 
Pitchblende from the Baiyanghe deposit also presents singular trace element signatures (Fig. 8C; Table 2; Table F). Pitchblende from sample 5434 has relatively high $\mathrm{Sr}$ (mean = $3243 \mathrm{ppm})$, Mo $($ mean $=1261 \mathrm{ppm}), \mathrm{Y}($ mean $=590 \mathrm{ppm})$ and $\mathrm{Ba}($ mean $=406 \mathrm{ppm})$ concentrations, low to very low mean values of $\mathrm{W}$ (83 ppm), $\mathrm{Nb}$ (40 ppm), $\mathrm{Zr}$ (12 ppm) and Ti (3 ppm), and negligible contents of Ta and Th. Non-altered pitchblende (V) from sample 5828 has high to very high mean values of $\mathrm{Nb}(17,890 \mathrm{ppm}), \operatorname{Zr}(5237 \mathrm{ppm})$, Ti (4047 ppm), W (3580 ppm), Y (3469 ppm), Th (721 ppm), Sr (555 ppm), Mo (449 ppm), and Ta (401 ppm), and a low mean value of Ba (78 ppm). Variably altered pitchblende (I) to (IV) and $\mathrm{Nb}$ /Ti-rich altered pitchblende show much higher contents of $\mathrm{Nb}$ (up to 93,800 ppm), Ti (up to $20,100 \mathrm{ppm}$ ), $\mathrm{Zr}$ (up to $12,080 \mathrm{ppm}$ ), $\mathrm{Sr}$ (up to $7155 \mathrm{ppm}$ ), Th (up to $5563 \mathrm{ppm}$ ), Ta (up to $5464 \mathrm{ppm}$ ) and $\mathrm{Ba}$ (up to $1700 \mathrm{ppm}$ ), and lower concentrations in Mo, W and Y (Figs. 8C-E). Furthermore, the higher $\mathrm{Nb}, \mathrm{Ti}$, $\mathrm{Th}$ and $\mathrm{Ta}$ concentrations tend to be positively correlated to higher $\mathrm{SiO}_{2}$ contents (Figs. 8D-E).

\subsection{In situ $U-P b$ isotopic dating on pitchblende}

Non-altered pitchblende from sample 5434, that is the most representative of the primary $\mathrm{U}$ mineralisation in the Baiyanghe deposit, was selected for in situ U-Pb isotopic dating in order to constrain the timing of the hydrothermal $U$ event with respect to the regional and local geological evolutions. Non-altered pitchblende (V) from sample 5828 was also considered for $\mathrm{U} / \mathrm{Pb}$ dating but it was damaged during sample preparation due to high degree of fracturing and it was not possible to perform SIMS analysis.

Based on back-scattered electron images obtained by SEM and preliminary EPMA analyses (Table D) performed on pitchblende, the largest and most suitable areas of pitchblende were selected for U-Pb in situ dating by SIMS. Special caution was taken in selecting zones devoid of galena inclusions, having relatively homogeneous $\mathrm{U}$ and $\mathrm{Pb}$ contents, and low Si contents and thus showing the less developed post-crystallisation 
alteration. The 38 analyses performed on pitchblende from sample 5434 display very high common lead contents with ${ }^{204} \mathrm{~Pb} /{ }^{206} \mathrm{~Pb}$ values ranging from 0.0146 to 0.0156 (Table $\mathrm{G}$ ). These analyses, corrected from common lead contamination, gave sub-concordant dates in Wetherill Concordia diagram spanning between 110 and $240 \mathrm{Ma}\left({ }^{207} \mathrm{~Pb} /{ }^{235} \mathrm{U}\right.$ age; Figure 9 and Table G). Such distribution does not allow the calculation of interpretable upper and lower intercepts (Fig. 9A) to determine the primary crystallisation age of pitchblende as well as the timing of its secondary alteration. In a Tera-Wasserburg diagram, the thirty-eight analyses, uncorrected for common lead contribution, plot in a strongly discordant position and do not allow the calculation of a plausible age (Fig. 9B). Results obtained in Wetherill and Tera-Wasserburg diagrams are linked to two processes: dominance of common lead compared to radiogenic lead and $\mathrm{Rn}$ leackage due to post-crystallization alteration (Ludwig and Simmons, 1992). Such a phenomenon was previously observed for uranium oxides, as for example from U deposits from the Armorican Massif in France (Ballouard et al., 2017b). As $\mathrm{Rn}$ is part of the disintegration chain of ${ }^{238} \mathrm{U}$ but not of ${ }^{235} \mathrm{U},{ }^{207} \mathrm{~Pb} /{ }^{235} \mathrm{U}$ ratios can be considered as less perturbed than ${ }^{206} \mathrm{~Pb} /{ }^{238} \mathrm{U}$ ratios and thus ${ }^{207} \mathrm{~Pb} /{ }^{235} \mathrm{U}$ ages are more accurate than ${ }^{206} \mathrm{~Pb} /{ }^{238} \mathrm{U}$ ages. Therefore, the oldest ${ }^{207} \mathrm{~Pb} /{ }^{235} \mathrm{U}$ date at $240 \pm 7 \mathrm{Ma}$ is considered as the minimum crystallisation age. Due to high common lead contribution, the U-Th-Pb chemical ages calculated after Bowles (1990) from the EPMA analyses on pitchblende showed meaningless peak ages (i.e., most of estimates are older than the host rocks; Fig. 9C).

\section{Discussion}

\subsection{The source(s) of uranium}

In the Xuemisitan Volcanic Belt, Devonian and late Carboniferous-middle Permian igneous rocks (Fig. 1; Li et al., 2015) characterise the major I-and A-type magmatic events that took place during the southward subduction of the Junggar oceanic crust and the closure of the oceanic basin between the Xuemisitan and Saur volcanic arcs (Choulet et al., 2011; 
Geng et al., 2011; Mao et al., 2014; Shen et al., 2012; Tang et al., 2010a; Wang et al., 2007; Yang et al., 2012; Yin et al., 2011). The West Junggar region then experienced a postorogenic stage (Choulet et al., 2012, 2011; Fig. 10) associated with intraplate magmatism and marked by multiple events of dyke intrusions until the late Triassic (Miao et al., 2019; Yi et al., 2014). In the Baiyanghe area, the late Devonian felsic volcanic and pyroclastic rocks of the Tarbagatay Group, and the late Carboniferous Yangzhuang granite porphyry represent the U source rocks for the mineralisation in the Baiyanghe deposit proposed in previous studies (Li et al., 2015; Mao et al., 2014; Shabaga et al., 2013; Zhang et al., 2019, 2020).

In the West Junggar region including the Xuemisitan belt, the large variety of mafic to felsic Devonian volcanic rocks show affinities with tholeiitic to calc-alkaline magmas originated from the partial melting of the mantle within a subduction zone (Chen et al., 2017; Wang et al., 2014; Xu et al., 2019; Yang, G.X. et al., 2014; Zhang et al., 2011). Nevertheless, late Devonian rhyolite and rhyolitic tuff in the Baiyanghe area belong to strongly fractionated magmatism of peralkaline affinity, equivalent to the A1-type granites of Eby (1992), with moderate to very high enrichment in incompatible elements such as $\mathrm{K}, \mathrm{Rb}, \mathrm{Nb}, \mathrm{Y}, \mathrm{Th}, \mathrm{Be}, \mathrm{Ta}$ and $\mathrm{U}\left(6.5<\mathrm{U}_{\text {mean }}<15.0 \mathrm{ppm}\right)$. These felsic volcanic rocks were most likely produced in an extensional setting after the closure of the Junggar oceanic domain (Filippova et al., 2001). Here, a subducted ridge (Choulet et al., 2011; Mao et al., 2014; Shen et al., 2011; Tang et al., 2010a; Wang et al., 2007) may have induced asthenosphere upwelling through a slab window, which would have provided the source of peralkaline magmas (Shen et al., 2011). Geochemical and isotopic features of Devonian volcanic rocks (e.g. $+4.33<\varepsilon \mathrm{Hf}(\mathrm{t})<+15.2$, $+0.2<\varepsilon \mathrm{Nd}(\mathrm{t})<+1.9$, and $\mathrm{Nd}$ model ages from 600 to $803 \mathrm{Ma}$; Mao et al., 2014; $\mathrm{Xu}$ et al., 2019) indicate that their parent magmas were derived from the partial melting of either an enriched mantle or a depleted mantle possibly metasomatised by slab-derived fluids, with relatively minor crustal contamination (De Paolo, 1988; Mao et al., 2014; Shen et al., 2012; 
Wang et al., 2014; Xu et al., 2019; Yang, G.X. et al., 2014; Zhang et al., 2011). For instance, it was proposed in Mao et al. (2014) that the very high $\mathrm{Nb}$ (up to $121 \mathrm{ppm}$ ) and Ta contents of these rocks originated from magmas produced by partial melting of $\mathrm{Nb}$-and Ta-rich amphibole-bearing metasomatised mantle wedge, which were further enriched during crystal fractionation. Hence, the strong magmatic enrichment of incompatible elements, especially $\mathrm{Nb}, \mathrm{Y}, \mathrm{Th}, \mathrm{Be}, \mathrm{Ta}$ and $\mathrm{U}$, in the late Devonian rhyolitic tuff within the Baiyanghe area mainly resulted from a high degree of crystal fractionation of the peralkaline magmas from which it was derived, as attested by very high $\mathrm{Fe} / \mathrm{Mg}$ and $\mathrm{Na} / \mathrm{K}$ ratios, low $\mathrm{Ca}$, Ti and $\mathrm{P}$ contents, high to very high concentrations of $\mathrm{Nb}, \mathrm{Ta}$, Th, $\mathrm{Y}$, and REE "gull-winged" pattern. Similar to the Streltsovka caldera in Russia (Chabiron et al., 2003, 2001), the relatively high proportion of volcanic glass in these rhyolitic tuffs has allowed significant $U$ and probably Be release during volcanic glass devitrification (Forbes et al., 1984; Walton et al., 1981) during hydrothermal alteration, which is corroborated by $\mathrm{Th} / \mathrm{U}$ ratios higher than 10 in altered zones (Table C; Fig. 3D).

Furthermore, the REE signatures of hydrothermal pitchblende in the Baiyanghe deposit are characterised by a typical "gull-winged" pattern, which shows strong similarities with those from the host rhyolitic tuff (Figs. 8A-B). Hence, it demonstrates that the REE signatures of U oxides from hydrothermal mineralisation mimic the REE patterns of the volcanic rocks from which the U was leached (Alexandre et al., 2016; Bonnetti et al., 2017, 2018a; Cuney et al., 1990; Frimmel et al., 2014; Mercadier et al., 2011; Perez-Soba et al., 2014), and thus characterise late Devonian peralkaline rhyolitic tuff as a major U source for the Baiyanghe deposit. Similar to U oxides, fractionated "gull-winged" REE patterns of the Be-ore stage dark purple fluorite (Fig. 8; Li et al., 2015), that is coeval with bertrandite, also identify the rhyolitic tuff as the prominent Be source at Baiyanghe. Moreover, the similar chemical signatures $(\mathrm{Pb}, \mathrm{Nb}, \mathrm{Zr}, \mathrm{Y}$, Th and $\mathrm{Ta})$ between the rhyolitic tuff and pitchblende constitute an 
additional line of evidence to argue that these tuffs represent a major source of $U$ for the mineralisation. Finally, ${ }^{206} \mathrm{~Pb} /{ }^{204} \mathrm{~Pb}$ ratios in rhyolite are lower than in the Yangzhuang granite (Li et al., 2015), which also suggest that the rhyolitic tuff may have been a major source of common $\mathrm{Pb}$ that was strongly enriched in pitchblende, although carbonaceous shales at the contact with the tuff likely represent an additional source of common $\mathrm{Pb}$. For instance, metavolcanic units were also proposed as a possible source of metals for common $\mathrm{Pb}$-rich pitchblende from granite-related U deposits in the French Armorican Massif of the European Hercynian Belt (Ballouard et al., 2017a; Bonhoure et al., 2007). Therefore, the late Devonian rhyolitic tuff represents the dominant $U$ and Be source for the hydrothermal mineralisation in the Baiyanghe deposit.

The late Carboniferous Yangzhuang granite porphyry belongs to a moderately fractionated weakly to moderately peraluminous moderate-to high-K calc-alkaline A2-type granite (according to Eby, 1992), with low to moderate enrichment in incompatible elements such as $\mathrm{K}, \mathrm{Y}, \mathrm{Nb}, \mathrm{Th}, \mathrm{Be}(\mathrm{mean}=4.7 \mathrm{ppm}), \mathrm{Ta}$ and $\mathrm{U}($ mean $=2.9 \mathrm{ppm})$. This characterisation of the Yangzhuang granite porphyry significantly differs from the interpretation that was proposed in previous studies (e.g. Li et al., 2015; Mao et al., 2014), where it was identified as a strongly fractionated A1-type granite and the most favorable source of uranium for the mineralisation in the Baiyanghe deposit. In this study, the whole rock composition of the Yangzhuang granite shows different geochemical features with, for example, much lower $\mathrm{Nb}$ and $\mathrm{U}$ contents compared with the data presented in Mao et al. (2014), Zhang and Zhang (2014) and Zhang et al. (2019) $\left(\mathrm{Nb}_{\text {mean }}=98 \mathrm{ppm}, \mathrm{U}_{\text {mean }}=17 \mathrm{ppm}\right)$. In fact, the geochemical signatures from these studies are very similar to those of the Devonian rhyolitic tuff (see data comparison in Figure 3). It is therefore possible that part of what is considered as the Yangzhuang granite porphyry in fact belongs to Devonian rhyolite. The Yangzhuang granite characterised by relatively low magmatic $U$ enrichment was derived from the partial melting 
of either juvenile continental crust (Chen and Arakawa, 2005) or metasomatised depleted mantle with heterogeneous crustal contamination (Han et al., 1997), as indicated by positive $\varepsilon \mathrm{Nd}(\mathrm{t})$ values (i.e. $+4.1-+5.9$; Mao et al., 2014) which are comparable with those of other A2type granites in West Junggar region (Han et al., 1998), combined with a wide range of the initial ${ }^{87} \mathrm{Sr} /{ }^{86} \mathrm{Sr}$ ratio (i.e. Mao et al., 2014).

Magmatic uraninite has never been observed in the Yangzhuang granite (Li et al., 2015; Zhang et al., 2019), however, metamict U-bearing accessory minerals including (U)-thorite, zircon and columbite showed evidence of $U$ release and remobilisation along the rock fractures (Zhang et al., 2020). Moreover, whole-rock geochemical data presented in Zhang et al. (2020) demonstrated that part of the $U$ and Be contents were leached out of the granite. Therefore, although the Yangzhuang granite represents a minor source of $U$ because of low $U$ contents, $\mathrm{Th} / \mathrm{U}$ ratios are close to chondritic values and $\mathrm{Nb} / \mathrm{Ta}$ and $\mathrm{Zr} / \mathrm{Hf}$ ratios (14-17 and 4245, respectively) characterise a barren granite according to Ballouard et al. (2016), the evidences provided by Zhang et al. (2020) of U release from accessory phases and $U$ and Be leaching from the whole rock suggest that the Yangzhuang granite may have partly contributed to the total $\mathrm{U}$ and Be budget in the Baiyanghe deposit.

\subsection{Hydrothermal uranium mineralisation}

The primary $\mathrm{U}$ mineralisation, mainly hosted in fractures along contact zones between the late Carboniferous Yangzhuang granite porphyry and late Devonian rhyolitic tuff, yielded a minimum crystallisation age of $240 \pm 7 \mathrm{Ma}$ on pitchblende. This is the first time that U-oxide was dated by in situ U-Pb isotopic techniques (i.e. SIMS) in this deposit; hence this age constrains a minimum age for the volcanic-related hydrothermal $U$ mineralisation stage in the Baiyanghe deposit (Fig. 10) that corresponds to the early Permian-middle Triassic postaccretion crustal extension in West Junggar (Choulet et al., 2012, 2011). This date is comparable with the oldest age (i.e. $238 \pm 3 \mathrm{Ma}$ ) previously obtained by U-Pb TIMS dating on 
pitchblende-bearing samples (Yi et al., 2016). In addition, cogenetic molybdenite (Li et al., 2015) suggests synchronous $U$ and Mo mineralisation. Pitchblende veins also exibit petrographic evidence that the hydrothermal $U$ event postdates $\mathrm{Be}$ ore-stage dark purple fluorite veins (Figs. 4 and 6). This is further corroborated by (i) different alteration/gangue mineral assemblages, a fluorite-quartz-chlorite-muscovite/illite-calcite-kaolinite assemblage for the Be-ore-stage while the $U$ mineralisation is only associated with quartz and calcite (Fig. $10 \mathrm{~A}$ ), possibly indicating different $f \mathrm{O}_{2}, \mathrm{pH}$ or temperature conditions of the ore fluids; and (ii) older ages obtained for coeval phases of the Be mineralisation compared with the crystallisation age of pitchblende determined in this study, including a $303 \pm 2 \mathrm{Ma}$ Ar-Ar age on muscovite (Li et al., 2015) and a $265 \pm 33 \mathrm{Ma} \mathrm{Sm}-\mathrm{Nd}$ age on dark purple fluorite (Yi et al., 2016). Nevertheless, considering the analytical errors of these isotopic ages, Be and U-Mo were deposited within the same mineralising event, even though they occur in two distinct stages in the paragenetic succession (Fig. 10). In addition, the minimum time gap of 10 to 70 Ma between the emplacement age of the Yangzhuang granite porphyry (313 $\pm 2 \mathrm{Ma})$ and the formation of the hydrothermal Be and U ores (ca. 303-240 Ma) tends to disprove the model of Li et al. (2015) who proposed that the hydrothermal Be-U mineralisation was genetically related to the Yangzhuang granite. In the Baiyanghe deposit, hydrothermal $\mathrm{U}$ mineralisation is characterised by non-altered pitchblende significantly enriched in $\mathrm{Pb}, \mathrm{Nb}, \mathrm{Zr}, \mathrm{W}$ and $\mathrm{Ti}$ with relatively high concentrations in $\mathrm{Y}$ and Mo. High contents of minor elements such as $\mathrm{Nb}$ and $\mathrm{Zr}$ together with REE element patterns reflect the geochemical signatures of the Devonian rhyolitic tuff that was characterised in section (5.1) as the prominent metal source rock for the mineralisation in the Baiyanghe deposit. For instance, $\mathrm{Zr}$ concentration in pitchblende is typically indicative of a volcanic source rock (Alexandre et al., 2016; Frimmel et al., 2014; Mercadier et al., 2011) as it can be easily released together with U during volcanic glass devitrification (Forbes et al., 1984). In addition to radiogenic $\mathrm{Pb}$, large amounts of common 
$\mathrm{Pb}$ characterised by SIMS analyses should derive from country rocks such as the Devonian rhyolitic tuff $\left(\mathrm{Pb}_{\text {mean }}=30 \mathrm{ppm}\right.$; Table $\left.\mathrm{C}\right)$.

The synchronous development of the Junggar Basin (Wang et al., 2019; Fig. 10B) and the Be-U-Mo hydrothermal system (ca. 303-240 Ma), at the origin of the volcanic-related Baiyanghe deposit during the early Permian-middle Triassic post-accretion event in West Junggar region, suggests that ore formation was controlled by crustal extension. During this extensional tectonic episode, the Baiyanghe area experienced multiple events of dyke intrusion (Miao et al., 2019; Yi et al., 2014), such as diorite (290 $\pm 18 \mathrm{Ma}, 222 \pm 18 \mathrm{Ma}$ ), dolerite (277 $\pm 6 \mathrm{Ma}, 272 \pm 4 \mathrm{Ma})$, diabase (255 Ma), and alaskite (255 $\pm 2 \mathrm{Ma}, 246 \pm 1 \mathrm{Ma})$. Diorite and dolerite intrusions were sub-concomittent with the Be mineralisation stage (ca. 303-265 Ma), while diabase and alaskite were emplaced slightly before the U-Mo mineralisation (at ca. $240 \mathrm{Ma}$ ). In this period of post-orogenic extension, the dykes are mostly indicative of the regional scale, higher heat flow generated by lithospheric and/or crustal thinning, which represents the main source of heat and driver for the hydrothermal system (e.g. Ballouard et a., 2017a,b; Bonnetti et al., 2020, 2018a). Although magmatic fluids may have been introduced locally in the basement during these episodes of mafic intrusions as suggested by $\mathrm{CO}_{2}$-bearing fluid inclusions in dark purple fluorite (Li et al., 2015), the dykes represent a negligible source of heat and fluids to the system. The preferred spatial distribution of the $U$ ore bodies at or near the intersection between these dykes and the main host-rocks (i.e. late Devonian rhyolitic tuff and late Carboniferous Yangzhuang granite; Li et al., 2015; $\mathrm{Xu}$ et al., 2017; Zhang et al. 2019) also suggests that they locally represent a favourable physicochemical environment (chemical trap) for the precipitation of the $U$ mineralisation from oxidised fluids, as they contain large amounts of reduced Fe-bearing minerals such as pyroxene, hornblende and biotite. Moreover, the relatively high Ti concentrations in pitchblende may have been mobilised from the mafic dykes $(1.35-2.70 \mathrm{wt} \%$ 
$\mathrm{TiO}_{2}$; Table A) by the mineralising fluids, as the host rocks of the Baiyanghe deposit have very low $\mathrm{Ti}$ contents $\left(\leq 0.22 \mathrm{wt} \% \mathrm{TiO}_{2}\right.$ in the Yangzhuang granite and $\leq 0.08 \mathrm{wt} \% \mathrm{TiO}_{2}$ in Devonian rhyolitic tuff). In addition, late Devonian carbonaceous shales of the Tarbagatay Group at the contact with the rhyolitic tuff represent another major reducing lithology that may have controlled the distribution and precipitation of the $U$ mineralisation (e.g. in the Guérande district, French Armorican Massif; Ballouard et al., 2017b; Figs. 2E and 2G).

Analyses of the fluid inclusions from dark purple fluorite that is cogenetic with the $\mathrm{Be}$ mineralisation in the Baiyanghe deposit indicated low temperatures of the hydrothermal system, ranging from 130 to $150{ }^{\circ} \mathrm{C}$ (Fayek and Shabaga, 2011; Li et al., 2015; Mao et al., 2013; Yang et al., 2014). These temperatures are consistent with low to moderate temperatures calculated from the chemical composition of hydrothermal chlorite (125$230{ }^{\circ} \mathrm{C}$; Zhang et al., 2019) also associated with bertrandite (Fig. 10A), a mineral which is stable at temperature $<250^{\circ} \mathrm{C}$ and indicative of an epithermal system (Barton, 1986; Foley et al., 2012). Based on $\mathrm{O}$ and $\mathrm{H}$ isotopic signatures $\left(-4.7<\delta^{18} \mathrm{O}<-3.2 \%\right.$ and $-110.6<\delta \mathrm{D}$ $<-56.0 \%$; Li et al., 2015) of hydrothermal muscovite associated with dark purple fluorite and bertrandite in veins, combined with the broadly ranging salinities measured in the fluid inclusions $(4.7 \%<\mathrm{NaCl}$ eq. $<19.7 \%)$, $\mathrm{Li}$ et al. (2015) proposed that the ore-forming solutions for the Be-U-Mo Baiyanghe deposit originated from the mixing between magmatic-derived fluids and local meteoric waters (Figs. 10 and 11). While all these characteristics support the contribution of low-temperature- and low-salinity meteoric waters to the system, the origin of the high-salinity fluids that may have mixed with these surface-derived waters remain speculative. Magmatic-derived fluids may have been introduced in the host rocks of the Baiyanghe deposit during the successive mafic dyke intrusions, as suggested by $\mathrm{CO}_{2}$-bearing fluid inclusions in fluorite ( $\mathrm{Li}$ et al., 2015). But the small volumes of magmatic fluids introduced in the basement by the dykes would be negligible. Oxidising basinal brines could 
have also been produced during the development of the Junggar Basin (Wang et al., 2019), hence providing a possible additional source of fluids and explaining the highest salinity values measured in fluid inclusions. For instance, the contribution of basin-derived waters to the ore-forming fluids in $U$ hydrothermal systems was previously proposed for mineralisation associated with granite in the Nanling Metallogenic Belt, South China (Bonnetti et al., 2018a; Zhang et al., 2017) and in the Armorican Variscan Belt, France (Ballouard et al., 2017b). As discussed in Li et al. (2015) and Zhang et al. (2019), the abundance of fluorite and other Fand/or Ca-bearing alteration minerals (e.g. muscovite, calcite; Fig. 10A) in the Baiyanghe deposit suggest that the ore-forming fluids were F-and Ca-rich solutions. As already characterised for micas from magmatic rocks related to U deposits (e.g. Chabiron et al., 2001; McPhie et al., 2011), F may have been released into aqueous solution during chloritisation of F-rich micas within the host rocks (e.g. 4.22-6.70 $\mathrm{wt} \% \mathrm{~F}$ in micas from the Yangzhuang granite; Li et al., 2015) or during volcanic glass devitrification $(0.03-0.06 \mathrm{wt} \% \mathrm{~F}$ in rhyolitic tuff; Li et al., 2015), while Ca most likely originated from the hydrothermal alteration of mafic dykes containing abundant Ca-rich minerals such as plagioclase and pyroxene.

In a first hydrothermal stage, oxidising meteoric and possibly basinal waters percolated downward into the basement through structures and mixed with $\mathrm{CO}_{2}$-bearing magmatic fluids derived from early generations of mafic dykes that intruded the host rocks in the Baiyanghe area. During the circulation of these thermal solutions along faults and fractured zones, Be was leached out of the volcanic glass and magmatic micas and feldspars (Foley et al., 2012; Kovalenko et al., 1977; London, 1997; Evensen and London, 2002) during the hydrothermal alteration of the host rocks. It was then transported in solution to the deposition site dominantly as fluoride and possibly minor carbonate ion complexes in the fluids (Li et al., 2015; Wood, 1992; Zhang et al., 2019). These ore solutions then reacted with Ca-rich minerals of the host rocks, which resulted in a $\mathrm{pH}$ increase that triggered fluorite precipitation 
in turn promoting Be deposition as bertrandite (Barton and Young, 2002; Foley et al., 2012; Li et al. 2015; Wood, 1992; Zhang et al., 2019). Therefore, $\mathrm{pH}$ variations and F removal from the fluids were likely the main destabilisation mechanisms of metal complexes controlling $\mathrm{Be}$ ore formation in the Baiyanghe deposit (Barton and Young, 2002; Li et al., 2015; Lindsey, 1981; Zhang et al., 2019). In a second stage, additional oxidising surface-derived fluids infiltrated the basement. Fluid inclusion study from post-Be-ore-stage white fluorite also indicated low temperatures of the hydrothermal system $\left(120-125^{\circ} \mathrm{C}\right.$; Li et al., 2015) and low to moderate salinity of the fluids $(7.3 \%<\mathrm{NaCl}$ eq. $<15.4 \%$; Li et al., 2015), indicating the contribution of meteoric fluids. However, the variation of salanity values suggests mixing processes between meteoric and basinal waters (e.g. Ballouard et al., 2017b). Moreover, REE signatures of post-Be-ore-stage fluorite characterised Cl-rich hydrothermal solutions ( $\mathrm{Li}$ et al., 2015), which is in agreement with the contribution of basinal brines (e.g. Richard et al., 2012). Additionally, the fact that pitchblende postdates fluorite veins, has low F contents (Table 1) and is mainly associated with calcite and quartz also excludes that $U$ was transported as fluoride complexes in the mineralising solutions. Therefore, during percolation and circulation of these oxidising fluids along opening fractures, $U$ was leached from the source rocks and likely transported as chlorine and/or uranyl carbonate complexes. These Ubearing solutions encountered favourable reducing environments mainly represented by dolerite and diabase dykes crosscutting the host rocks (Fig. 1C; Xu et al., 2017) and/or carbonaceous shale at the contact with the Devonian rhyolitic tuff (Fig. 2G), which induced a $f \mathrm{O}_{2}$ decrease of the fluids and promoted $\mathrm{U}$ precipitation as pitchblende (Zhang et al., 2019). Therefore, the Baiyanghe Be-U-Mo deposit primarily formed in a two-stage hydrothermal mineralisation model (e.g. Wang et al., 2012; Yi et al., 2016; Zhang et al., 2019), where different characteristics of the ore fluids and deposition mechanisms may explain why Be and U mineralisation formed in two distinct stages. 


\subsection{Post-ore hydrothermal alteration}

In the Baiyanghe deposit, the $U$ mineralisation experienced post-ore hydrothermal potassic alteration mainly characterised by abundant illite crystallisation replacing pitchblende or along secondary fractures (Figs. 4A-B and 5). In sample 5828, the chemical compositions of pitchblende (I) to (IV) and $\mathrm{Nb}$ /Ti-rich altered pitchblende showed variable degrees of postcrystallisation alteration characterised by low to very high Si contents (e.g. Martz et al., 2019), broadly ranging from 0.27 to $22.21 \mathrm{wt} \% \mathrm{SiO}_{2}$ (Table 1). The negative correlation between $\mathrm{Si}$ and $\mathrm{Pb}$ in altered pitchblende (Fig. 7D) also suggests radiogenic $\mathrm{Pb}$ loss during post-crystallisation alteration (Ludwig, 1978; Martz et al., 2019), which is also reflected by the wide range of U-Pb dates obtained by SIMS (i.e. 110-240 Ma; Fig. 9A). Moreover, altered pitchblende has significantly higher $\mathrm{Nb}, \mathrm{Ti}$, $\mathrm{Th}$ and $\mathrm{Ta}$ concentrations (up to 20.22 ${ }_{w t} \% \mathrm{Nb}_{2} \mathrm{O}_{5}, 7.19 \mathrm{wt} \% \mathrm{TiO}_{2}, 5563 \mathrm{ppm}$ Th and $\left.5464 \mathrm{ppm} \mathrm{Ta}\right)$ than non-altered pitchblende (Figs. 7E-F and 8C-E), which show positive correlation with Si contents. The enrichment in these elements may have resulted from a relative in situ concentration increase due to the loss of up to $>20 \mathrm{wt} \% \mathrm{UO}_{2}$ from pitchblende during the post-ore alteration. In the Baiyanghe deposit, hyperspectral characteristics of drill cores from deep $U$ mineralised sections also identified an alteration envelop with intense illite crystallisation along structures $(\mathrm{Xu}$ et al., 2017). A late generation of diorite dyke intrusion (i.e. at $222 \pm 18 \mathrm{Ma}$; Miao et al., 2019; Yi et al., 2014) postdating the formation of the primary $U$ mineralisation is evidence for an active phase of crustal extension, which may have favoured further fluid circulation in the basement. It may also have provided additional magmatic fluids to the system that could have driven this stage of post-ore hydrothermal alteration. However, this might be restricted to the vicinity of the dykes as not all the ore was affected by this hydrothermal alteration. For instance, pitchblende from sample 5434 shows no feature of post-ore hydrothermal alteration.

\subsection{Supergene uranium mineralisation}


As revealed in extensive studies conducted by Fayek and Shabaga (2011) and Shabaga et al. (2013) on the Be-U ore from the Baiyanghe deposit, a large majority of the $U$ mineralisation occurs as secondary $U$ minerals. Indeed, this secondary $U$ mineralisation is mainly represented by uranophane and minor hexavalent $U$ silicate replacing pitchblende in re-opened veins or filling a new set of fractures (Figs. 4 and 6), associated with $\mathrm{Pb} / \mathrm{Ti}$-, Mnand Mo-oxides, calcite, quartz, barite and hematite (Li et al., 2015; Shabaga et al., 2015, 2013; Zhang et al., 2019; Fig. 10A). This mineral assemblage indicates that the hydrothermalrelated ore was most likely oxidised by surface-derived fluids (i.e. meteoric waters) that percolated into the host rocks through structures during Mesozoic-Cenozoic crustal extension in West Junggar (Shabaga et al., 2015; Wang et al., 2019; Figs. 10B and 11). The youngest date at $110 \pm 2$ Ma obtained by SIMS analysis on pitchblende (Fig. 9A; Table G) could reflect the time when the $\mathrm{U}-\mathrm{Pb}$ isotopic system was re-opened, hence constraining the timing of secondary ore oxidation. This hypothesis is consistent with $\mathrm{U}-\mathrm{Pb}$ isotopic ages on uranophane ranging from $20 \mathrm{Ma}$ to $130 \mathrm{Ma}$ (Shabaga et al., 2015), which also suggest that the Baiyanghe deposit experienced multiple stages of supergene oxidation. These phases of ore oxidation were most likely controlled by alternating periods of crustal extension and tectonic uplift during late Mesozoic-Cenozoic in West Junggar (Wang et al., 2019), which favoured host rocks fracture and weathering related to meteoric fluid percolation through structures. Therefore, the primary hydrothermal $U$ ore characterised by pitchblende was oxidised. Mineral textures described in this study (Fig. 4) and in Shabaga et al. (2013) suggest that oxidising fluids (meteoric water) altered pitchblende and fluorite, leaching $\mathrm{U}, \mathrm{Ca}, \mathrm{F}, \mathrm{Pb}, \mathrm{Ti}$ and $\mathrm{Mn}$ that were remobilised in situ from the ore minerals and/or from the host rocks. Shabaga et al. (2013) proposed that an acidic solution deriving from pyrite oxidation was responsible for $\mathrm{U}$ remobilisation and that a change in $\mathrm{pH}$ conditions of the fluid caused the precipitation of uranophane and associated minerals $\mathrm{Pb} / \mathrm{Ti}$-and Mn-oxides (Fig. 10A). 


\subsection{Implications for uranium metallogenesis in the West Junggar}

The combined mineralogical, trace element and $\mathrm{U}-\mathrm{Pb}$ isotopic signatures of the $\mathrm{U}$ mineralisation in the Baiyanghe deposit led to: (i) the characterisation of a pitchblendedominated primary hydrothermal U stage along with its alteration features; and (ii) the definition of the timing (i.e. $240 \pm 7 \mathrm{Ma}$ ) of the structurally-controlled volcanic-related hydrothermal U deposits in the Xuemisitan belt, in West Junggar. Late Devonian strongly fractionated rhyolite or rhyolitic tuffs most probably of peralkaline A1-type affinity were identified as a major host rock for the mineralisation and the dominant $\mathrm{U}$ and also Be source. The late Carboniferous moderately fractionated weakly to moderately peraluminous moderate-to high-K calc-alkaline A2-type Yangzhuang granite represents an additional host rock for the mineralisation and a minor $U$ source. Therefore, fractionated peralkaline felsic volcanic rocks from the late Devonian Tarbagatay Group in the Xuemisitan belt represent highly valuable exploration guides for the discovery of similar volcanic-related $U$ deposits in the province. It was also demonstrated that the hydrothermal $U$ mineralisation has close spatial relationships with Devonian carbonaceous shale of the Tarbagatay Group (Fig. 2E) and mafic dykes that have intruded the host rocks during the early Permian-middle Triassic post-accretion crustal extenion in West Junggar (Xu et al., 2017; Zhang et al., 2019). Hence, the spatial distribution of these shale and dykes likely control the ore geometry, and their regional association with Devonian felsic volcanic rocks would also constitute U-prospective areas. Moreover, hydrothermal mineral assemblage and zoning associated with the hydrothermal Be-U mineralisation could be used as proxy to identify mineralised zones $(\mathrm{Xu}$ et al., 2017; Zhang et al., 2019). For instance, hyperspectral alteration information such as illite crystallinity was used by $\mathrm{Xu}$ et al. (2017) to identify surface signatures and illite typology zoning that may highlight pathways of hydrothermal fluids and narrow down the location of the mineralisation (e.g. Be ore-stage and U post-ore stage illite; Fig. 10A). 
The detailed characterisation of a structurally controlled pitchblende-dominated hydrothermal mineralisation stage in the Baiyanghe deposit and its geochronological constraint to the middle Triassic (ca. $240 \mathrm{Ma}$ ) represents a new contribution to the $\mathrm{U}$ metallogenesis in the West Junggar region. This low-temperature hydrothermal event was mainly controlled by the infiltration of meteoric and possibly basinal waters in basement rocks during the early Permian-middle Triassic post-accretion crustal extension in the region. We also demonstrated that hydrothermal $\mathrm{U}$ mineralisation postdates the Be-ore stage and that $\mathrm{U}$ deposition was mainly promoted by $f \mathrm{O}_{2}$ decrease when oxidised U-bearing solutions encountered favourable reducing environment such as carbonaceous shale and mafic dykes. This new model therefore proposes that hydrothermal processes were at the origin of the primary $\mathrm{U}$ ore formation characterised by $\mathrm{Pb}-\mathrm{Nb}$-Ti-Zr-Mo-rich pitchblende, which was further enriched in $\mathrm{Nb}, \mathrm{Ti}, \mathrm{Th}$, and $\mathrm{Ta}$ during dyke-emplacement related post-ore hydrothermal alteration. This hydrothermal ore stage finally reveals that asthenospheric upwelling induced by a ridge subduction during the late Devonian (Choulet et al., 2011; Shen et al., 2011; Tang et al., 2010a; Wang et al., 2007) may have produced favourable volcanic host rocks and $\mathrm{U}$ sources derived from fractionated peralkaline magmas.

Finally, there are major differences between $U$ metallogenesis in the Baiyanghe deposit and genetic models proposed in other provinces showing volcanic-related $U$ deposits. Compared with the largest district in the world, the Streltsovka caldera in Russia characterised by U-Mo-F mineralisation (Chabiron et al., 2003, 2001), the Baiyanghe deposit is associated with a graben-like structure and a much smaller caldera, with low dipping tectonic structures, ore deposition largely postdates the emplacement of the host rocks, the $\mathrm{U}$ mineralisation was deposited after an early Be-F mineralisation episode, and the primary $\mathrm{U}$ ore was intensively oxidised by supergene processes. Another comparison may be done with Spor Mountain (Thomas Range, western Utah), representing the world's largest economic deposits of 
berylium characterised by $\mathrm{Be}$ and $\mathrm{U}$ mineralisation associated with fluorite in a volcanic environment (Lindsey, 1981; Burt and Sheridan, 1985). At Spor Mountain, the Be ore associated with anomalous amounts of $U$ occurs in volcanic tuff and tuffaceous sandstone along the ring fault of the Oligocene Thomas caldera. The occurrence of $\mathrm{Be}$ and $\mathrm{U}$ in fluorspar indicates coprecipitation of fluorite, bertrandite, and $U$ (probably dispersed in the fluorite lattice; no $\mathrm{U}$ mineral has been identified in fluorite). The proposed mechanism for precipitation is declining fluorine activity in cooling hydrothermal fluids. Similar to Baiyanghe, the host volcanic rocks (tuff and rhyolite) were identified as the predominant $\mathrm{U}$ and Be source for the mineralisation. REE patterns in zircon and other geochemical signatures characterised by Ayuso et al. (2020) reflected the interplay of alkaline (A-type) trachytic to rhyolitic magma enriched in $\mathrm{Be}, \mathrm{U}, \mathrm{Li}$, and $\mathrm{F}$ and a protracted history of fractional crystallisation. Moreover, secondary U mineralisation also occurred, separately from Be and fluorite in the Be tuff member. Under near-surface temperatures and oxidising conditions, $U$ may have been mobilised as uranyl carbonate complexes. As no reducing material (e.g. pyrite or organic matter) has been identified and no uraninite has been found, $U$ is interpretated to have precipitated as uranophane and other oxidised minerals such as weeksite.

\section{Conclusions}

The volcanic-related Be-U-Mo Baiyanghe deposit located in the Paleozoic Xuemisitan Volcanic Belt in West Junggar (NW China) represents the largest Be deposit in Asia and a significant resource for $\mathrm{U}$. The $\mathrm{U}$ mineralisation is predominantly hosted in late Devonian rhyolitic tuff and in the late Carboniferous Yangzhuang granite porphyry. The late Devonian rhyolitic tuff is a strongly fractionated peralkaline A1-type volcanic rock that represents the dominant $\mathrm{Be}$ and $\mathrm{U}$ source for the mineralisation. This volcanic rock was produced by magmas derived from partial melting of either an enriched mantle or a depleted mantle possibly metasomatised by slab-derived fluids, with relatively minor crustal contamination. 
These peralkaline magmas were strongly fractionated and enriched in incompatible elements, especially $\mathrm{Nb}, \mathrm{Y}, \mathrm{Th}, \mathrm{Be}$, Ta and $\mathrm{U}$. Rhyolitic tuff has elevated $\mathrm{U}$ concentrations $\left(6.5<\mathrm{U}_{\text {mean }}\right.$ $<15.0 \mathrm{ppm}$ ), which were leached by the hydrothermal ore-forming fluids during volcanic glass devitrification. The late Carboniferous Yangzhuang granite is a moderately fractionated weakly to moderately peraluminous moderate-to high-K calc-alkaline A2-type granite, which was derived from partial melting of either juvenile continental crust or metasomatised depleted mantle with heterogeneous crustal contamination. This granite is characterised by low magmatic $\mathrm{U}$ and $\mathrm{Be}$ enrichment $\left(\mathrm{U}_{\text {mean }}=2.9 \mathrm{ppm} ; \mathrm{Be}_{\text {mean }}=4.7 \mathrm{ppm}\right)$ and constitutes a minor $U$ and Be source for the mineralisation. Nevertheless, evidences of $U$ release from metamict accessory $U$ phases (uranothorite, zircon, columbite) and $U$ and Be leaching from the whole rock indicate that the Yangzhuang granite likely contributed to the $\mathrm{U}$ and Be budget in the Baiyanghe deposit.

The combined mineralogical, trace element and $\mathrm{U}-\mathrm{Pb}$ isotopic signatures of the $\mathrm{U}$ mineralisation from the Baiyanghe deposit allowed the characterisation of a primary hydrothermal $U$ mineralisation stage and its alteration features. The hydrothermal vein-type U mineralisation is mainly characterised by $\mathrm{Pb}-\mathrm{Nb}$-Ti-Zr-Mo-rich pitchblende associated with calcite and quartz. This event, constrained by an in situ U-Pb isotopes minimum crystallisation age of $240 \pm 7 \mathrm{Ma}$ on pitchblende, occurred during the early Permian-middle Triassic post-accretion event in West Junggar and postdated the Be ore stage in the paragenetic succession. The Be-U-Mo ore formation that was controlled by an extensional tectonic regime followed a two-stage hydrothermal model within the same mineralising event: (i) oxidising meteoric and possibly basinal waters percolated downward into the basement through structures and mixed with $\mathrm{CO}_{2}$-bearing magmatic fluids derived from early generations of mafic dykes that intruded the host rocks in the Baiyanghe area. During the circulation of these thermal solutions along faults and fractured zones, Be was leached mainly 
from the late Devonian rhyolitic tuff during hydrothermal alteration and dominantly transported as fluoride complexes in the fluids. These ore solutions then reacted with Ca-rich minerals of the host rocks, which resulted in a $\mathrm{pH}$ increase that triggered fluorite precipitation in turn promoting Be deposition as bertrandite; and (ii) in a second stage, additional oxidising surface-derived fluids including meteoric waters and possibly basinal brines infiltrated the basement. U was also leached mainly from the late Devonian rhyolitic tuff and likely transported as chlorine and/or uranyl carbonate complexes in the fluids. U precipitation as pitchblende was mainly promoted by $\mathrm{fO}_{2}$ decrease when these oxidised U-bearing solutions encountered favourable reducing environment mainly represented by dolerite and diabase dykes crosscutting the host rocks and/or carbonaceous shales at the contact with the Devonian rhyolitic tuff. Pitchblende also locally experienced dyke-emplacement related post-ore hydrothermal potassic alteration characterised by abundant illite crystallisation, significant $\mathrm{Si}$ gain and in situ relative enrichment of $\mathrm{Nb}, \mathrm{Ti}$, Th, and $\mathrm{Ta}$ due to strong $\mathrm{U}$ and $\mathrm{Pb}$ depletion. Then, the primary $U$ mineralisation was largely oxidised into uranophane due to supergene alteration related to further meteoric water infiltration during late Mesozoic-Cenozoic crustal extension in West Junggar.

Finally, the characteristics of the volcanic-related hydrothermal Be-U mineralisation in the Baiyanghe deposit showed key similarities with Streltsovka (Russia) and Spor Mountain (USA) world-class distrcits (e.g. U mainly hosted and/or derived from volcanic tuff, fluorite as a major gangue mineral), although the Baiyanghe resources are much smaller than the ones of the Streltsovka caldera.

\section{Acknowledgements}

Financial support for this study was provided by the East China University of Technology in Nanchang and by the Bureau of Geology of the China National Nuclear Corporation (BOG, CNNC). The authors are grateful to the colleagues from the Geological Team No. 216, BOG, 
CNNC in Urumqi, Xinjiang, for their field support and the access to the mine and exploration sites. We acknowledge the collaboration of Dr Xuefen Zhang for the petrographic observations performed by SEM and Mr Guangxu Chen for the sample preparation. We also acknowledge the Ion Probe Team of Nancy (IPTN) for the help in acquiring the in-situ U-Pb isotopic data on pitchblende. Finally, the authors would like to thank Dr Shihua Zhong and one anonymous reviewer for improving this paper.

\section{References}

Alexandre, P., Kyser, K., Layton-Matthews, D., Joy, B., 2016. Chemical compositions of natural uraninite. Can. Mineral. 53-4, 595-622.

Ayuso, R.A., Foley, N.K., Vazquez, J.A., Jackson, J.C. 2020. SHRIMP U-Pb zircon geochronology of volcanic rocks hosting world class Be-U mineralization at Spor mountain, Utah, U.S.A. J. Geochemical Exploration 209, 106401.

Ballouard, C., Poujol, M., Boulvais, P., Branquet, Y., Tartèse, R., Vigneresse, J-L., 2016. NbTa fractionation in peraluminous granites: A marker of the magmatic-hydrothermal transition. Geology 44, 231-234.

Ballouard, C., Poujol, M., Boulvais, P., Mercadier, J., Tartèse, R., Venneman, T., Deloule, E., Jolivet, M., Kéré, I., Cathelineau, M., Cuney, M., 2017a. Magmatic and hydrothermal behavior of uranium in syntectonic leucogranites: The uranium mineralization associated with the Hercynian Guérande granite (Armorican Massif, France). Ore Geol. Rev. 80, 309-331.

Ballouard, C., Poujol, M., Mercadier, J., Deloule, E., Boulvais, P., Baele, J.-M., Cuney, M., Cathelineau, M., 2017b. Uranium metallogenesis of the peraluminous leucogranite from the Pontivy-Rostrenen magmatic complex (French Armorican Variscan belt): the result of long term oxidized hydrothermal alteration during strike-slip deformation. Miner. Deposita. http://dx.doi.org/10.1007/s00126-017-0761-5.

Barton, M.D., 1986. Phase equilibria and thermodynamic properties of minerals in the BeO 
A12O3-SiO2-H2O (BASH) system, with petrologic applications. Am. Mineral. 71, 277-300.

Barton, M.D., Young, S., 2002. Non-pegmatitic deposits of beryllium: mineralogy, geology, phase equilibria and origin. Rev. Mineral. Geochem. 50, 591-691.

Bonhoure, J., Kister, P., Cuney, M., Deloule, E., 2007. Methodology for rare earth element determinations of uranium oxides by ion microprobe. Geostand. Geoanal. Res. 31, 209-225.

Bonnetti, C., Cuney, M., Bourlange, S., Deloule, E., Poujol, M., Liu, X., Peng, Y., Yang, J., 2017. Primary uranium sources for sedimentary-hosted uranium deposits in NE China: insight from basement igneous roks of the Erlian Basin. Miner. Deposita 52, 297-315.

Bonnetti, C., Liu, X., Mercadier, J., Cuney, M., Deloule, E., Villeneuve, J., Liu, W., 2018a. The genesis of granite-related hydrothermal uranium deposits in the Xiazhuang and Zhuguang ore fields, North Guangdong Province, SE China: Insights from mineralogical, trace elements and $\mathrm{U}-\mathrm{Pb}$ isotopes signatures of the $\mathrm{U}$ mineralisation. Ore Geol. Rev. 92, 588-612.

Bonnetti, C., Riegler, T., Liu, X., 2018b. Alteration fingerprint of the early Yanshanian granite-related high-temperature hydrothermal uranium mineralisation in the Nanling Metallogenic Belt, SE China. In: International Symposium on Uranium Raw Material for the Nuclear Fuel Cycle: Exploration, Mining, Production, Supply and Demand, Economics and Environmental Issues (URAM-2018). CN-261-83, IAEA, Vienna, 45-48.

Bonnetti, C., Liu, X., Mercadier, J., Cuney, M., Riegler, T., Yu, C., 2020. Evolution of the uranium mineralisation in the Zoujiashan deposit, Xiangshan ore field: Implications for the genesis of volcanic-related hydrothermal U deposits in South China. Ore Geol. Rev. 122, 103514.

Bowles, J.F.W., 1990. Age dating of individual grains of uraninite in rocks from electron microprobe analyses. Chem. Geol. 83, 47-53.

Burt, D., Sheridan, M.F., 1985. Relation of topaz rhyolite volcanism to uranium mineralization in the western United States of America. In Uranium deposits in volcanic 
rocks. Proc. technical committee meeting, El Paso, 1984, (IAEA; STI/PUB/690) (pp. 337$345)$.

Cathelineau, M., Boiron, M.C., Holliger, P., Poty, B., 1990. Metallogenesis of the French part of the Variscan orogen. Time-space relationships between $\mathrm{U}, \mathrm{Au}$ and $\mathrm{Sn}-\mathrm{W}$ ore deposition and geodynamic events - mineralogical and U-Pb data. Tectonophysics 177, 59-79.

Chabiron, A., Alyoshin, A., Cuney, M., Golubev, V., Velitchkin, V., Deloule, E., Poty, B., 2001. Geochemistry of the rhyolitic magmas associated with the Streltsovka uranium deposits (Tranbaikalia): a magmatic inclusion study. Chem. Geol. 175, 273-290.

Chabiron, A., Cuney, M., Poty, B., 2003. Possible uranium sources for the largest uranium district associated with volcanism: The Streltsovka caldera (Transbaikalia, Russia). Miner. Deposita 38, 127-140.

Chen, B., Arakawa, Y., 2005. Elemental and Nd-Sr isotopic geochemistry of granitoids from the West Junggar foldbelt (NW China), with implications for Phanerozoic continental growth. Geochim. Cosmochim. Acta 69, 1307-1320.

Chen, J.F., Han, B.F., Ji, J.Q., Zhang, L., Xu, Z., He, G.Q., Wang, T., 2010. Zircon U-Pb ages and tectonic implications of Paleozoic plutons in northern West Junggar, North Xinjiang, China. Lithos 115 (1-4), 137-152.

Chen, Y., Xiao, W., Windley, B.F., Zhang, J., Zhou, K., Sang, M., 2017. Structures and detrital zircon ages of the Devonian-Permian Tarbagatay accretionary complex in west Junggar, China: imbricated ocean plate stratigraphy and implications for amalgamation of the CAOB. Int. Geol. Rev. 59, 1097-1115.

Choulet, F., Chen, Y., Wang, B., Faure, M., Cluzel, D., Charvet, J., Lin, W., Xu, B., 2011. Late Paleozoic paleogeographic reconstruction of Western Central Asia based upon paleomagnetic data and its geodynamic implications. J. Asian Earth Sci. 42, 867-884.

Choulet, F., Faure, M., Cluzel, D., Chen, Y., Lin, W., Wang, B., Jahn, B.M., 2012. 
Architecture and evolution of accretionary orogens in the Altaids Collage: the early paleozoic West Junggar. American J. Sci. 312, 1098-1145.

Compston, W., Williams, I.S., Meyer, C.E., 1984. U/Pb geochronology of zircons from lunar breccias 73217 using a sensitive high mass res- olution ion microprobe. In: Proceedings of the 14th Lunar and Planetary Science Conference, Part 2. J. Geophys. Res. 89B, 525-534.

Cuney, M., Friedrich, M., Blumenfeld, P., Bourgignon, A., Boiron, M.C., Vigneresse, J.L., Poty, B., 1990. Metallogenesis in the French part of the Variscan orogeny. Part I: Upreconcentrations in the pre-Variscan and Variscan formations - A comparison with Sn, W, and Au. Tectonophysics 177, 39-57.

De Paolo, D.J., 1988. Neodynium isotope geochemistry: an introduction. Springer, New York.

Deloule, E., Alexandrov, P., Cheilletz, A., Laumonier, B., Barbey, P., 2002. In-situ U-Pb ages for early Ordovician magmatism in the eastern Pyrenees, France: the Canigou orthogneisses. Int. J. Earth Sci. 91, 398-405.

Didenko, A.N., Morozov, O.L., 1999. Geology and paleomagnetism of Middle-Upper Paleozoic rocks of the Saur Ridge. Geotectonics 4, 64-80 (in Russian with English abstract).

Eby, G.N., 1992. Chemical subdivision of the A type granitoids: Petrogenetic and tectonic implications. Geology 20, 641-644.

Evensen, J.M., London, D., 2002. Experimental silicate mineral/melt partition coefficients for beryllium and the crustal Be cycle from migmatite to pegmatite. Geochim. Cosmochim. Acta $66,2239-2265$.

Fayek, M., Shabaga, B., 2011. The BaiYangHe beryllium deposit, NW China. Intern. Rep. 126.

Filippova, I.B., Bush, V.A., Didenko, A.N., 2001. Middle Paleozoic subduction belts: the leading factor in the formation of the Central Asian fold-and-thrust belt. Russian Journal of 
Earth Sciences 3, 405-426.

Foley, N.K., Hofstra, A.H., Lindsey, D.A., Seal, R.R., Jaskula, B., Piatak, N.M., 2012. Occurrence model for volcanogenic beryllium deposits. Chapter F of mineral deposit models for resource assessment. In: U.S. Geological Survey. Scientific Investigations Report 20105070-F, pp. 1-43.

Foley, N.K., Jaskula, B.W., Piatak, N.M., Schulte, R.F., 2017. Beryllium, chap. E of Schulz, K.J., DeYoung, J.H., Jr., Seal, R.R., II, and Bradley, D.C., eds., Critical mineral resources of the United States-Economic and environmental geology and prospects for future supply. U.S.G.S. Professional Paper 1802, E1-E32.

Forbes, P., Pacquet, A., Chantret, F., Oumarou, J., Pagel, M., 1984. Marqueurs du volcanisme dans le gisement d'uranium d'Akouta (République du Niger). CR Acad. Sci. Paris 298, 647650.

Frimmel, H.E., Schedel, S., Brätz, H., 2014. Uraninite chemistry as forensic tool for provenance analysis. Appl. Geochem. 48, 104-121.

Geng, H.Y., Sun, M., Yuan, C., Xiao, W.J., Xian, W.S., Zhao, G.C., Zhang, L.F., Wong, K., Wu, F.Y., 2009. Geochemical, Sr-Nd and zircon U-Pb-Hf isotopic studies of Late Carboniferous magmatism in the West Junggar, Xinjiang: implications for ridge subduction? Chem. Geol. 266, 364-389.

Geng, H.Y., Sun, M., Yuan, C., Zhao, G.C., Xiao, W.J., 2011. Geochemical and geochronological study of early Carboniferous volcanic rocks from the West Junggar: petrogenesis and tectonic implications. J. Asian Earth Sci. 42, 854-866.

Han, B.F., He, G.Q., Wang, S.G., Hong, D.W., 1998. Post-collisional mantle-derived magmatism and vertical growth of the continental crust in North Xinjiang. Geol. Rev. 44, 396-406 (in Chinese with English abstract).

Han, B.F., Wang, S.G., Jahn, B., Hong, D.W., Kagami, H., Sun, Y.L., 1997. Depleted-mantle 
source for the Ulungur River A-type granites from North Xinjiang, China: geochemistry and $\mathrm{Nd}-\mathrm{Sr}$ isotopic evidence, and implications for Phanerozoic crustal growth. Chem. Geol. 138, 135-159.

Han, B.F., Guo, Z.J., He, G.Q., 2010. Timing of major suture zones. in North Xinjiang, China: constraints from stitching plutons. Acta Petrol. Sin. 26, 2233-2246 (in Chinese with English abstract).

IAEA, 2016. World distribution of uranium deposits (UDEPO). TECDOC-1843.

ICS, International Commission on Stratigraphy, 2016. International Stratigraphic Chart.

Kovalenko, V.I., Antipin, V.S., Petrov, L.L., 1977. Distribution coefficients of Be in ongonites and some notes on its behavior in the rare metal lithium-fluorine granites. Geochem. Int. 14, 129-141.

Kuibida, M.L., Kruk, N.N., Vladimirov, A.G., Polyanskii, N.V., Nikolaeva, I.V., 2009. U-Pb isotopic age, composition, and sources of the plagiogranites of the Kalba range, Eastern Kazakhstan. Doklady Earth Sci. 424, 72-76.

ICS, International Commission on Stratigraphy, 2016. International stratigraphic chart.

Lach, P., Mercadier, J., Dubessy, J., Boiron, M.C., Cuney, M., 2013. In situ quantitative measurement of rare earth elements in uranium oxides by laser ablation-inductively coupled plasma-mass spectrometry. Geostand. Geoanal. Res. 37-3, 277-296.

Lederer, G.W., Foley, N.K., Jaskula, B.W., Ayuso, R.A., 2016. Beryllium-A Critical Mineral Commodity-Resources, Production, and Supply Chain (No. 2016-3081). U.S. Geological Survey, Reston.

Li, X.F., Wang, G., Mao, W., Wang, C.Z., Xiao, R., Wang, M., 2015. Fluid inclusions, muscovite Ar-Ar age, and fluorite trace elements at the Baiyanghe volcanic Be-U-Mo deposit, Xinjiang, northwest China: implication for its genesis. Ore Geol. Rev. 64, 387-399.

Lindsey, D.A., 1977. Epithermal beryllium deposits in water-laid tuff, western Utah. Econ. 
Geol. 72, 219-232.

Lindsey, D.A., 1981. Volcanism and uranium mineralization at Spor Mountain, Utah, in Goodell, P.C., and Waters, A.C., eds., Uranium in volcanic and volcaniclastic rocks. AAPG Studies in Geology 13, 89-98.

Lindsey, D.A., Ganow, H., Mountsoy, W., 1973. Hydrothermal alteration associated with beryllium deposits at Spor Mountain, Utah. In: Geological Survey Professional Paper. U.S Government Printing Office, pp. A1-A20.

London, D., 1997. Estimating abundances of volatile and other mobile components in evolved silicic melts through mineral-melt equilibria. J. Petrol. 38, 1691-1706.

Ludwig, K.R., 1978. Uranium-daughter migration and U/Pb isotope apparent ages of uranium ores, Shirley Basin, Wyoming. Econ. Geol. 73-1, 29-49.

Ludwig, K.R., 1999. Isoplot/Ex version 2.00; a geochronological toolkit for Microsoft Excel Special Publication - Berkeley Geochronological Center, 49 pp.

Ludwig, K.R., Simmons, K.R., 1992. U-Pb dating of uranium deposits in collapsebreccia pipes of the Grand Canyon Region. Econ. Geol. 87, 1747-1765.

Mao, W., Wang, G., Li, X.F., Wang, M., Xiao, R., 2013. A study of fluid inclusions in Baiyanghe U-Be deposit, Xinjiang. Miner. Depos. 32, 1026-1034 (in Chinese with English abstract).

Mao, W., Li, X.F., Wang, G., Xiao, R., Wang, M., Li, Y.L., Ren, M.C., Bai, Y.P., Yang, F., 2014. Petrogenesis of the Yangzhuang Nb, Ta-rich A-type granite porphyry in the West Junggar, Xinjiang, China. Lithos 198-199, 172-183.

Martz, P., Mercadier, J., Perret, J., Villeneuve, J., Deloule E., Cathelineau, M., Quirt, D., Doney, A., Ledru, P., 2019. Post-crystallization alteration of natural uraninites: Implications for dating, tracing, and nuclear forensics. Geochim. Cosmochim. Acta 249, 138-159.

McDonough, W.F., Sun, S., 1995. The composition of the Earth. Chem. Geol., 120, 223-253. 
McPhie, J., Kamenetsky, V., Allen, S., Ehrig, K., Agangi, A., Bath, A., 2011. The fluorine link between a supergiant ore deposit and a silicic large igneous province. Geology 39, 1003006.

Mercadier, J., Cuney, M., Lach, P., Boiron, M-C., Bonhoure, J., Richard, A., Leisen, M., Kister, P., 2011. Origin of uranium deposits revealed by their rare earth element signature. Terra Nova 23, 264-269.

Miao, X.Q., Zhang, X., Zhang, H., Wang, J.R., 2019. Geochronological and geochemical studies of the OIB-type Baiyanghe dolerites: implications for the existence of a mantle plume in northern West Junggar (NW China). Geol. Mag. 156, 702-724 (in Chinese with English abstract).

Paton C., Hellstrom J., Paul B., Woodhead J. and Hergt J. (2011) Iolite: Freeware for the visualisation and processing of mass spectrometric data. J. Anal. At. Spectrom. 26, 25082518.

Pearce, N.J.G., Perkins, W.T., Westgate, J.A., Gorton, M.P., Jackson, S.E., Neal, C.R., Cheney, S.P., 1997. A compilation of new and published major and trace element data for NIST SRM 610 and NIST SRM 612 glass reference materials. Geostand. Geoanal. Res. 21, $115-144$

Perez-Soba, C., Villaseca, C., Orejana, D., Jeffries, T., 2014. Uranium-rich accessory minerals in the peraluminous and perphosphorous Belvis de Monroy pluton (Iberian Variscan belt). Contrib. Mineral. Petrol. 167, 1008.

Richard, A., Rozsypal, C., Mercadier, J., Banks, D.A., Cuney, M., Boiron, M-C., Cathelineau, M., 2012. Giant uranium deposits formed from exceptionally uranium-rich acidic brines. Nature Geoscience 5, 142-146.

Rudnick, R.L., Gao, S., 2004. Composition of the Continental Crust. In: Treatise on Geochemistry. Holland, H.D., and Turekian, K.K., (eds), Elsevier, Amsterdam, 3, 1-64. 
Shabaga, B.M., Fayek, M., Wang, G., Wen, Z., 2013. Petrography and geochemistry of the Baiyanghe volcanic-hosted Be-U deposit, Xinjiang Autonomous Region, NW China. Geol. Soc. Am. 45, Denver, U.S.A.

Shabaga, B., Fayek, M., Marlatt, J., Wang, G., Zhou, J., Wen, Z., 2015. Geochronology and mineralogy of the Baiyanghe volcanic-hosted Be-U deposit, Xinjiang, NW China. GSA Annual Meeting in Baltimore, Maryland, USA, paper 122-7.

Shen, X., Zhang, H., Wang, Q., Wyman, D.A., Yang, Y., 2011. Late Devonian-Early Permian A-type granites in the southern Altay Range, Northwest China: Petrogenesis and implications for tectonic setting of “A2-type” granites. J. Asian Earth Sci. 42, 986, 1007.

Shen, P., Shen, Y.C., Li, X.H., Pan, H.D., Zhu, H.P., Meng, L., Dai, H.W., 2012. Northwestern Junggar Basin, Xiemisitai Mountains, China: a geochemical and geochronological approach. Lithos 140, 103-118.

Stacey, J.S., Kramers, J.D., 1975. Approximation of Terrestrial lead isotope evolution by a two-stage model. Earth Planet. Sci. Letts. 26, 207-221.

Tang, G.J., Wang, Q., Zhao, Z.H., Wyman, D.A., Chen, H.H., Jia, X.H., Jiang, Z.Q., 2009. Geochronology and geochemistry of the ore-bearing porphyries in the Baogutu area (Western Junggar): petrogenesis and their implications for tectonics and $\mathrm{Cu}-\mathrm{Au}$ mineralization. Earth Sci. 34, 56-74 (in Chinese with English abstract).

Tang, G.J., Wang, Q., Wyman, D.A., Li, Z.X., Zhao, Z.H., Jia, X.H., Jiang, Z.Q., 2010a. Ridge subduction and crustal growth in the Central Asian Orogenic Belt: evidence from Late Carboniferous adakites and high-Mg diorites in the western Junggar region, northern Xinjiang (west China). Chem. Geol. 277, 281-300.

Tang, G.J., Wang, Q., Wyman, D.A., Sun, M., Li, Z.X., Zhao, Z.H., Sun, W.D., Jia, X.H., Jiang, Z.Q., 2010b. Geochronology and geochemistry of Late Paleozoic magmatic rocks in the Lamasu-Dabate area, northwestern Tianshan (west China): evidence for a tectonic 
transition from arc to post-collisional setting. Lithos 119, 393-411.

Taylor, S.R., McLennan, S.M., 1985. The Continental Crust; Its composition and evolution; an examination of the geochemical record preserved in sedimentary rocks. Blackwell, Oxford. Vladimirov, A.G., Kruk, N.N., Khromykh, S.V., Polyansky, O.P., Chervov, V.V., Vladimirov, V.G., Travin, A.V., Babin, G.A., Kuibida, M.L., Vladimirov, V.D., 2008. Permian magmatism and lithospheric deformation in the Altai caused by crustal and mantle thermal processes. Russian Geol. Geophy. 49, 468-479.

Walton, A.W., Galloway, W.E., Henry, C.D., 1981. Release of uranium from volcanic glass in sedimentary sequences; an analysis of two systems. Econ. Geol. 76-1, 69-88.

Wang, F.T., 2006. The Paleogeographic and Geo-ecological Atlas of Xinjiang Uygur Autonomous Region. SinoMaps Press, Beijing p. 226 (in Chinese with English abstract).

Wang, B., Chen, Y., Zhan, S., Shu, L., Faure, M., Cluzel, D., Charvet, J., Laurent-Charvet, S., 2007. Primary Carboniferous and Permian paleomagnetic results from the Yili Block (NW China) and their implications on the geodynamic evolution of Chinese Tianshan Belt. Earth Planet. Sci. Lett. 263, 288-308.

Wang, M., Li, X.F., Wang, G., Li, Y.L., Shi, Z.L., Lu, K.G., 2012. Geological characteristics of Baiyanghe berylluium-uranium deposits in Xuemisitan volcanic belt, Xinjiang. Miner. Explor. 3, 34-40 (in Chinese with English abstract).

Wang, H., Xu, X., Chen, J., Guo, L., Xi, R., 2014. Petrogenesis of volcanic rocks from Early Devonian Marasu Formation, West Juggar. Acta Petrol. Sin. 30, 3553-3568.

Wang, Y., Liu, L., Ji, H., Song, G., Wang, X., Sheng, Y., 2019. Structure of a pre-Triassic unconformity and its hydrocarbon transporting characteristics, Wuerhe-Fengnan area, Junggar Basin, China. J. Petrol. Sci. Engin. 173, 820-834.

Wood, S.A., 1992. Theoretical prediction of speciation and solubility of beryllium in hydrothermal solution to $300{ }^{\circ} \mathrm{C}$ at saturated vapor pressure: application to 
bertrandite/phenakite deposits. Ore Geol. Rev. 7, 249-278.

Xiao, Y.D., Huang, J.H., Wang, Z., Wang, S.C., Zhou, Y.B., Li, Q.D., 2011. The spatial distribution Be and U orebodies at Baiyanghe deposit, Xinjiang. Explor. Eng. 9, 123-126.

Xiu, X.X., Fan, H.H., Ma, H.F., Yi, L.S., 2011. Hydrothermal alteration and its geochemical characteristics at Baiyanghe U-Be deposit, Xinjiang, NW China. Uranium Geol. 27 (4), 215222.

Xu, Q.J., Ye, F.W., Liu, S.F., Zhang, Z.X., Zhang, C. 2017. Hyperspectral Alteration Information from Drill Cores and Deep Uranium Exploration in the Baiyanghe Uranium Deposit in the Xuemisitan Area, Xinjiang, China. Remote Sensing 451, 1-21.

Xu, Q., Li, Y., Yang, G., Ning, W., Tong, L., Duan, F., Wu, L., Ren, P., 2019. Petrogenesis and tectonic setting of the Middle Devonian Beitashan Formation volcanic rocks in the northern East Junggar, NW China: Insights from geochemistry, zircon U-Pb dating, and $\mathrm{Hf}$ isotopes. Geol. J.

Yang, W., Fayek, M., Li, Y., Wang, M., Zhou, J., 2014. Characteristics of Fluid Inclusions and fluorite of Baiyanghe Beryllium deposit in Western Junggar. Xinjiang Geol. 2014-01 (in Chinese with English abstract).

Yang, G.X., Li, Y.J., Gu, P.Y., Yang, B.K., Tong, L.L., Zhang, H.W., 2012. Geochronological and geochemical study of the Darbut Ophiolitic Complex in the West Junggar (NW China): implications for petrogenesis and tectonic evolution. Gondwana Res. 21, 1037-1049.

Yang, G.X., Li, Y., Safonova, I., Yi, S., Tong, L., Seltman, R., 2014. Early Carboniferous volcanic rocks of West Junggar in the western Central Asian Orogenic Belt: Implications for a supra-subduction system. Int. Geol. Rev. 56, 823-844.

Yi, L.S., Li. Y., Ma, H., 2014. An Exploration-Evaluation Model for Uranium-Beryllium Resources in Xuemisitan Volcanic Belt, NW Xinjiang, China. Acta Geol. Sin. (English 
Edition), 88, 1422-1423.

Yi, L.S., Fan H.R., Zhai M.G., Li, Y.X., Ma, H.F., Tian, J.J., Xiu, X.Q., 2016. Fluorite Sm$\mathrm{Nd}$ isochron and pitchblende $\mathrm{U}-\mathrm{Pb}$ dating in the Baiyanghe $\mathrm{Be}-\mathrm{U}$ deposit, Xinjiang and their geological significances. Acta Petrol. Sin. 32, 2099-2110.

Yin, J.Y., Yuan, C., Sun, M., Long, X.P., Zhao, G.C., Wong, K.P., Geng, H., Cai, K., 2010. Late Carboniferous high-Mg dioritic dikes in Western Junggar, NW China: geochemical features, petrogenesis and tectonic implications. Gondwana Res. 17, 145-152.

Yin, J.Y., Yuan, C., Wang, Y.J., Long, X.P., Guan, Y.L., 2011. Magmatic records on the Late Paleozoic tectonic evolution of Western Junggar, Xinjiang. Geotec. Metall. 35, 278-291 (in Chinese with English abstract).

Zhang, X., Zhang, H., 2014. Geochronological, geochemical, and Sr-Nd-Hf isotopic studies of the Baiyanghe A-type granite porphyry in the Western Junggar: implications for its petrogenesis and tectonic setting. Gondwana Res. 25, 1554-1569.

Zhang, L., Li, X., Wang, G., Wang, M., 2020. Direct evidence for the source of uranium in the Baiyanghe deposit from accessory mineral alteration in the Yangzhuan granite prophyry, Xinjiang Province, Northwest China. American. Min. 105, 1556-1571.

Zhang, L., Li, X., Wang, G., Wang, M., Yang, W., Zhang, L., Zhu, Y., 2019. Hydrothermal alteration and mineral chemistry of the giant Baiyanghe Be-U deposit in Xinjiang, northwest China: Implications for its mineralization. Ore Geol. Rev. 111, 102972.

Zhang, J., Xiao, W., Han, C., Mao, Q., Ao, S., Guo, Q., Ma, C., 2011. A Devonian to Carboniferous intra-oceanic subduction system in Western Junggar, NW China. Lithos 125, 592-606.

Zhao, L., He, G., 2013. Tectonic entities connection between West Junggar (NW China) and East Kazakhstan. J. Asian Earth Sci. 72, 25-32.

Zhong, S.h., Seltmann, R., Shen, P., 2017. Two different types of granitoids in the Suyunhe 
large porphyry Mo deposit, NW China and their genetic relationships with molybdenum mineralization. Ore Geol. Rev. 88, 116-139.

Zou, T.R., 2006. REE and Rare Metal Deposits in Xinjiang, China. Geological Publishing House, Beijing p. 284. 


\section{Figures}
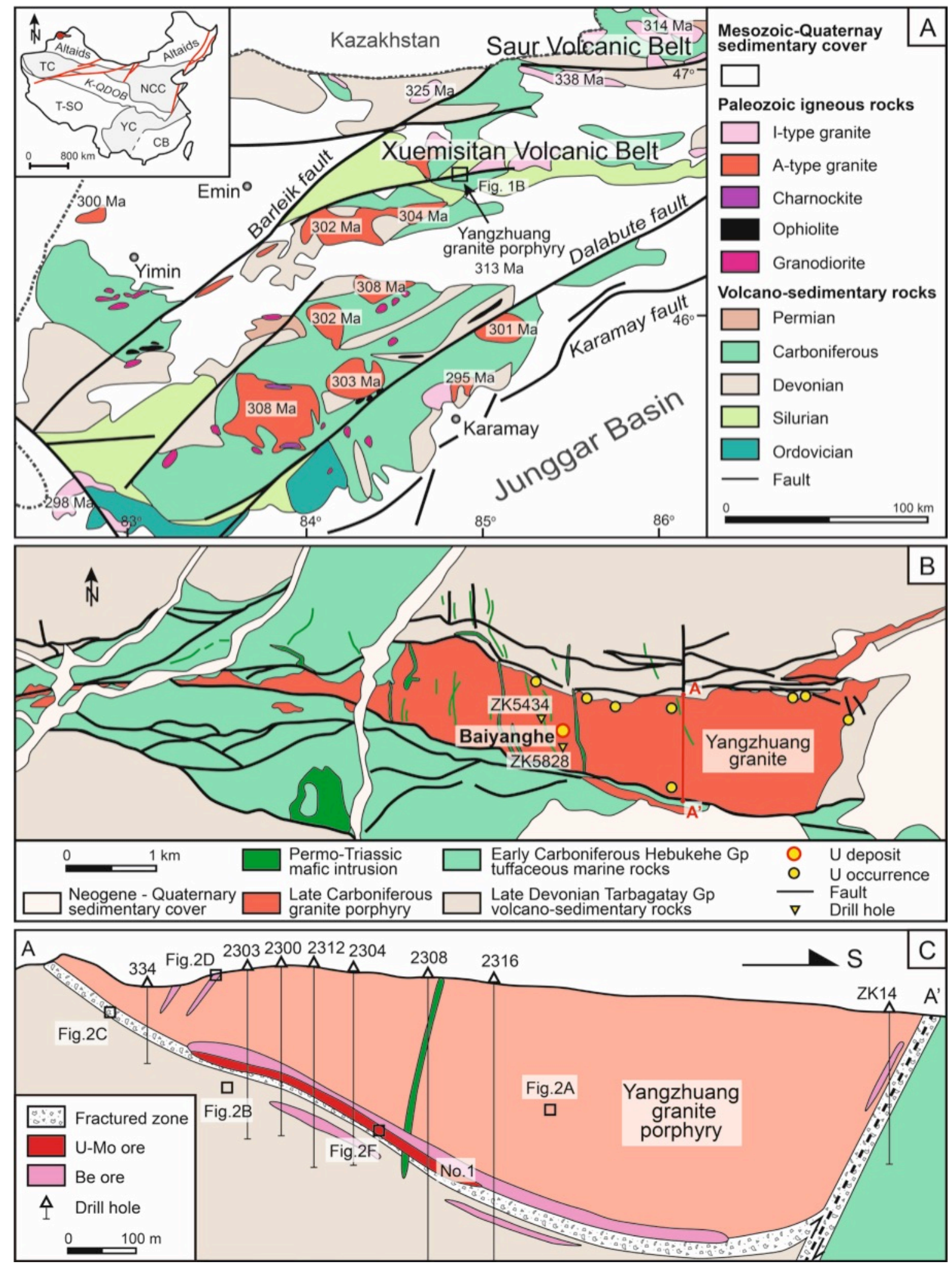

Figure 1, (A) Simplified geological map of West Junggar, Xinjiang, NW China (modified after Li et al., 2015; Mao et al., 2014; Zhang et al., 2019); (B) Geological map of the Baiyanghe area (modified after Li et al., 2015; Mao et al., 2014; Zhang et al., 2019); (C) Cross section of the Baiyanghe U-BeMo deposit showing the spatial distribution of ore bodies (modified after Li et al., 2015; Xu et al., 2017; Zhang et al., 2019). 


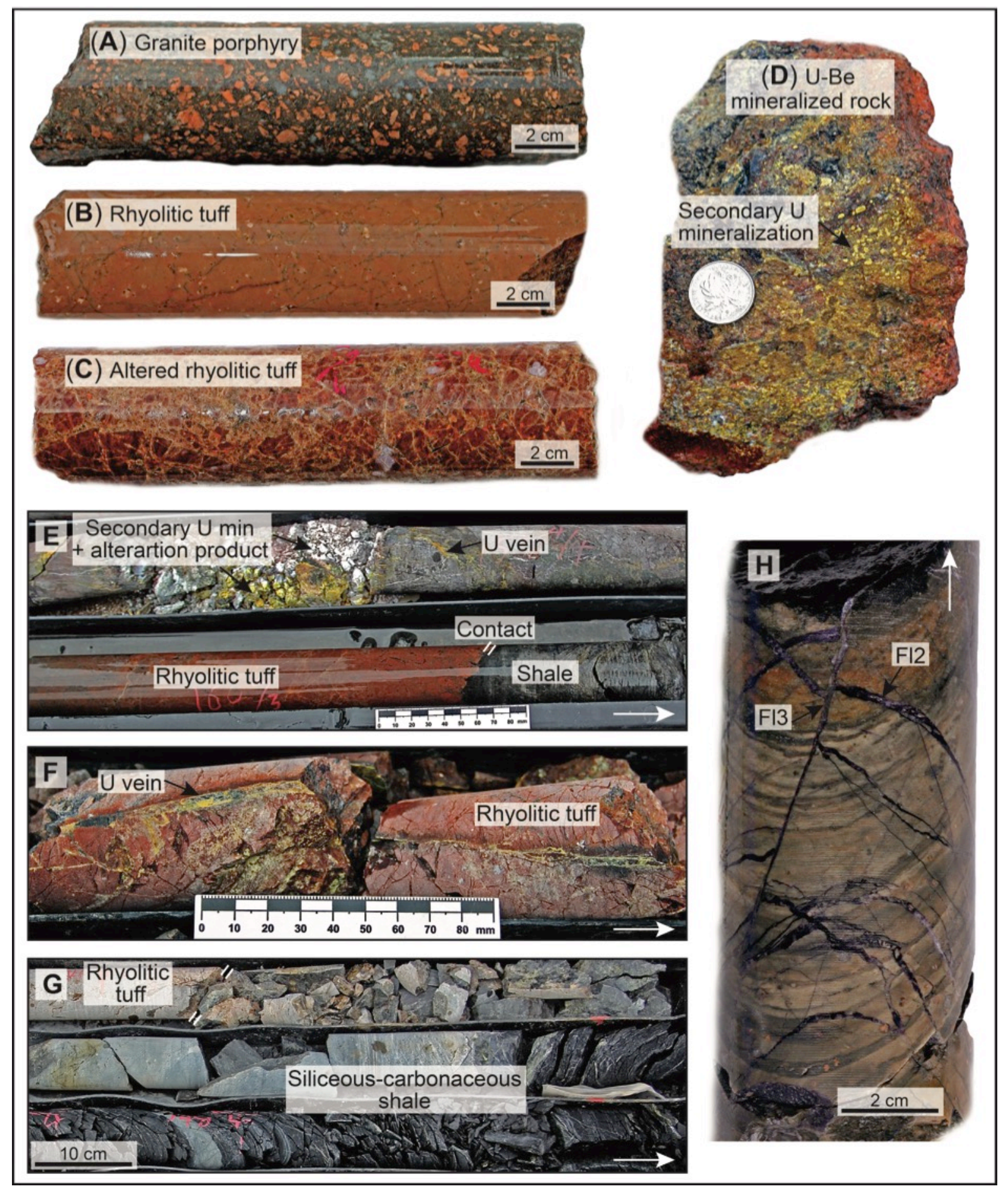

Figure 2, Representative photographs of the host rocks and mineralised sections from the Baiyanghe deposit. (A) Drill core sample of the late Carboniferous Yangzhuang granite porphyry; (B) Drill core sample of rhyolitic tuff from the late Devonian Tarbagatay Group; (C) Drill core sample of fractured and altered rhyolitic tuff from the late Devonian Tarbagatay Group; (D) Rock-chip sample of the U-Be mineralised Yangzhuang granite showing secondary U mineralisation; (E) Mineralised drill core section of Devonian rhyolitic tuff showing secondary $U$ mineralisation along with alteration minerals in fractures, near contact with carbonaceous shale; (F) Mineralised drill core section of Devonian rhyolitic tuff showing primary and secondary $U$ mineralisation in vein; $(\mathrm{G})$ Contact zone between rhyolitic tuff and siliceous-carbonaceous shale of the Tarbagatay Group; (H) Ore-stage fluorite veins in siliceous-carbonaceous shale of the Tarbagatay Group. 

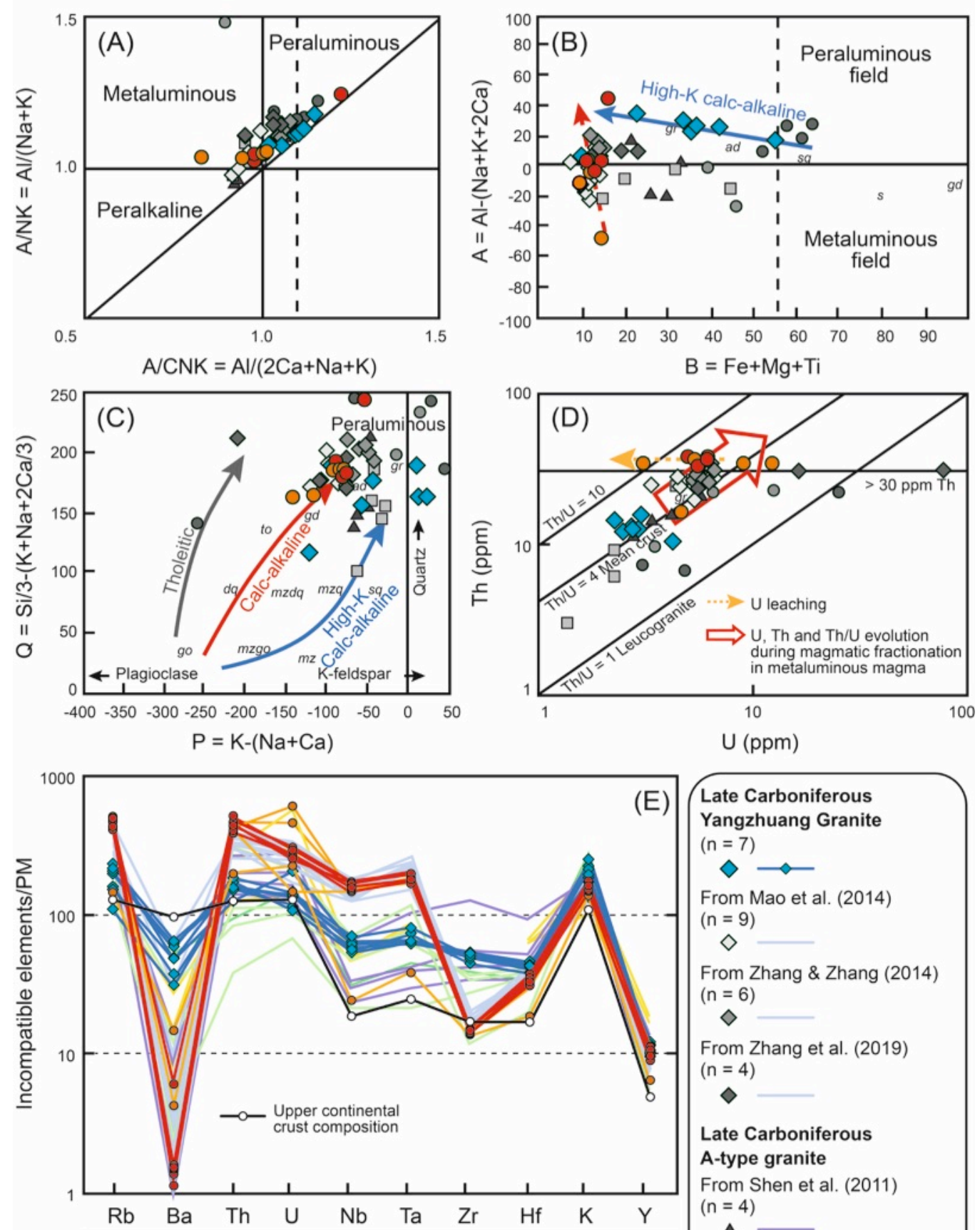

Late Carboniferous Yangzhuang Granite $(n=7)$

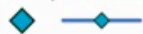

From Mao et al. (2014) $(n=9)$

$\diamond$

From Zhang \& Zhang (2014) $(n=6)$

$\diamond$

From Zhang et al. (2019) $(n=4)$

$\diamond$

Late Carboniferous

A-type granite

From Shen et al. (2011) $(n=4)$

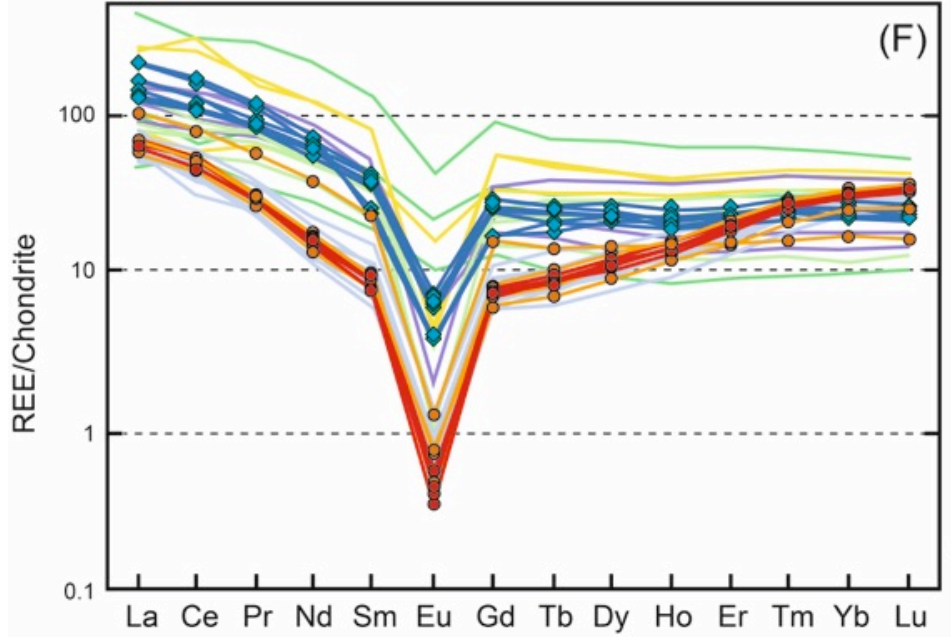

ate Devonian Rhyolitic tuff $(n=9)$

$\begin{array}{ll}\longrightarrow & \text { Non-altered } \\ 0 & -\end{array}$

From Zhang et al. (2019) $(n=3)$

O

Late Devonian Rhyolite

From Zhang et al. (2019) $(n=4)$

0

Late Devonian A-type granite From Shen et al. (2011)

$(n=5)$

$\square$ 
Figure 3, Whole-rock geochemical signatures of the late Carboniferous Yangzhuang granite porphyry and late Devonian rhyolitic tuff in the Baiyanghe area. (A) A/NK vs A/CNK diagram showing the metaluminous to peraluminous characters of the rhyolitic tuff and peraluminous characters of the granite porphyry; (B) A vs B diagram showing the variations of the aluminous index (A parameter) relative to a differentiation index (B parameter) displaying A-type magmatic fractionation trends; (C) Q vs $\mathrm{P}$ diagram showing the variations in quartz content relative to the variations of proportions of Kfeldspar and plagioclase; (D) Th vs $U$ diagram showing $\mathrm{U}$, Th and $\mathrm{Th} / \mathrm{U}$ evolution during magmatic fractionation in metaluminous magma from which the rhyolitic tuff and granite porphyry are derived; (E) Primitive mantle (PM) normalised concentrations of incompatible elements; (F) Chondritenormalised REE patterns. For comparison, whole-rock geochemical compositions of the Yangzhuang granite from Mao et al. (2014), Zhang and Zhang (2014) and Zhang et al. (2019), the Late Devonian rhyolite and rhyolitic tuff from Zhang et al. (2019), and additional compositions of Late Devonian and Late Carboniferous A-type granites from Shen et al. (2011) are indicated with symbols in shades of grey in the diagrams. Major elements, $\mathrm{A} / \mathrm{NK}, \mathrm{A} / \mathrm{CNK}$ (in cations), $\mathrm{A}, \mathrm{B}, \mathrm{Q}$ and $\mathrm{P}$ values (in millications) are presented in Table $\mathrm{A} . \mathrm{A} / \mathrm{NK}=$ agpaicity; $\mathrm{A} / \mathrm{CNK}=$ aluminum saturation index; $\mathrm{A}=$ excess of alumina not bound to the feldspars; $\mathrm{B}=$ differentiation index; $\mathrm{Q}=$ estimate of quartz content obtained by subtracting silica bound to the feldspar from the total silica content of the rock; $\mathrm{P}=$ proportion of K-feldspar (positive) relative to plagioclase (negative). $\mathrm{gr}=$ granite, ad = adamellite, $\mathrm{gd}$ $=$ granodiorite, to $=$ tonalite, $\mathrm{mzq}=$ quartz-monzonite, $\mathrm{mzdq}=$ quartz-monzodiorite; $\mathrm{s}=$ syenite; $\mathrm{sq}=$ quartz-syenite; $\mathrm{dq}=$ quartz-diorite; go = gabbro; $\mathrm{mzgo}=$ monzo gabbro-diorite; $\mathrm{mz}=$ monzonite. See REE concentrations in Table B; Th, $\mathrm{U}$ and other incompatible elements contents in Table C. Chondrite composition is from Taylor and McLennan (1985). Upper continental crust composition is from Rudnick and Gao (2004). Composition of the primitive mantle is from McDonough and Sun (1995). 

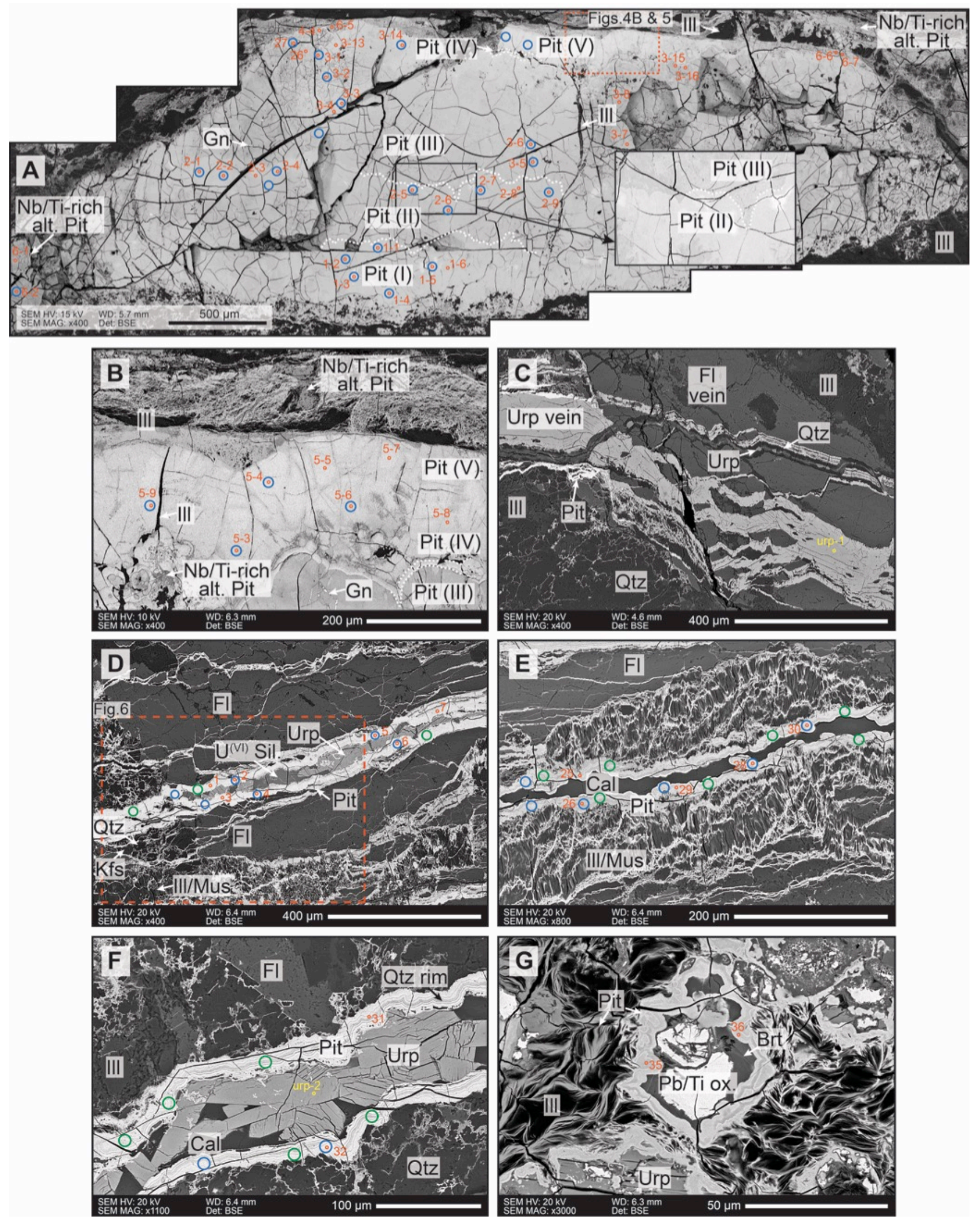
Figure 4, Back-scattered electron images of the uranium mineralisation from the Baiyanghe deposit. (A) Pitchblende vein showing five bands of hydrothermal growth, associated with illite, galena and $\mathrm{Nb}$ /Ti-rich altered pitchblende (sample 5828); (B) Pitchblende (III) to (V) associated with illite, galena and $\mathrm{Nb}$ /Ti-rich altered pitchblende (sample 5828); (C) Pitchblende and uranophane veins crosscutting Be ore-stage fluorite vein (sample 5434); (D) Pitchblende-hexavalent U silicate-uranophane vein crosscutting Be ore-stage fluorite vein (sample 5434); (E) Pitchblende-calcite vein crosscutting Be ore-stage fluorite vein and replacing earlier illite/muscovite vein (sample 5434); (F) Alternating pitchblende and microcrystalline vein lately re-opened and filled with uranophane and calcite (sample 5434); (G) Pitchblende replaced by uranophane associated with $\mathrm{Pb}$ /Ti-oxide and barite (sample 5434). Alt. = altered; $\mathrm{Brt}=$ barite; $\mathrm{Cal}=$ calcite $\mathrm{U}^{(\mathrm{VI})} \mathrm{Sil} .=$ hexavalent $\mathrm{U}$ silicate; $\mathrm{Fl}=$ fluorite; $\mathrm{Gn}=$ galena; $\mathrm{Ill}=$ illite; Kfs = K-feldspar; Mus = muscovite; Pit = pitchblende; Qtz = quartz; Urp = uranophane. Orange circles (pitchblende) and yellow circles (uranophane) indicate the location of EPMA datapoints. Blue circles indicate the location of LA-ICP-MS and green circles the location of SIMS measurements on pitchblende. The white dashed lines show the boundaries between the different pitchblende growth bands. 


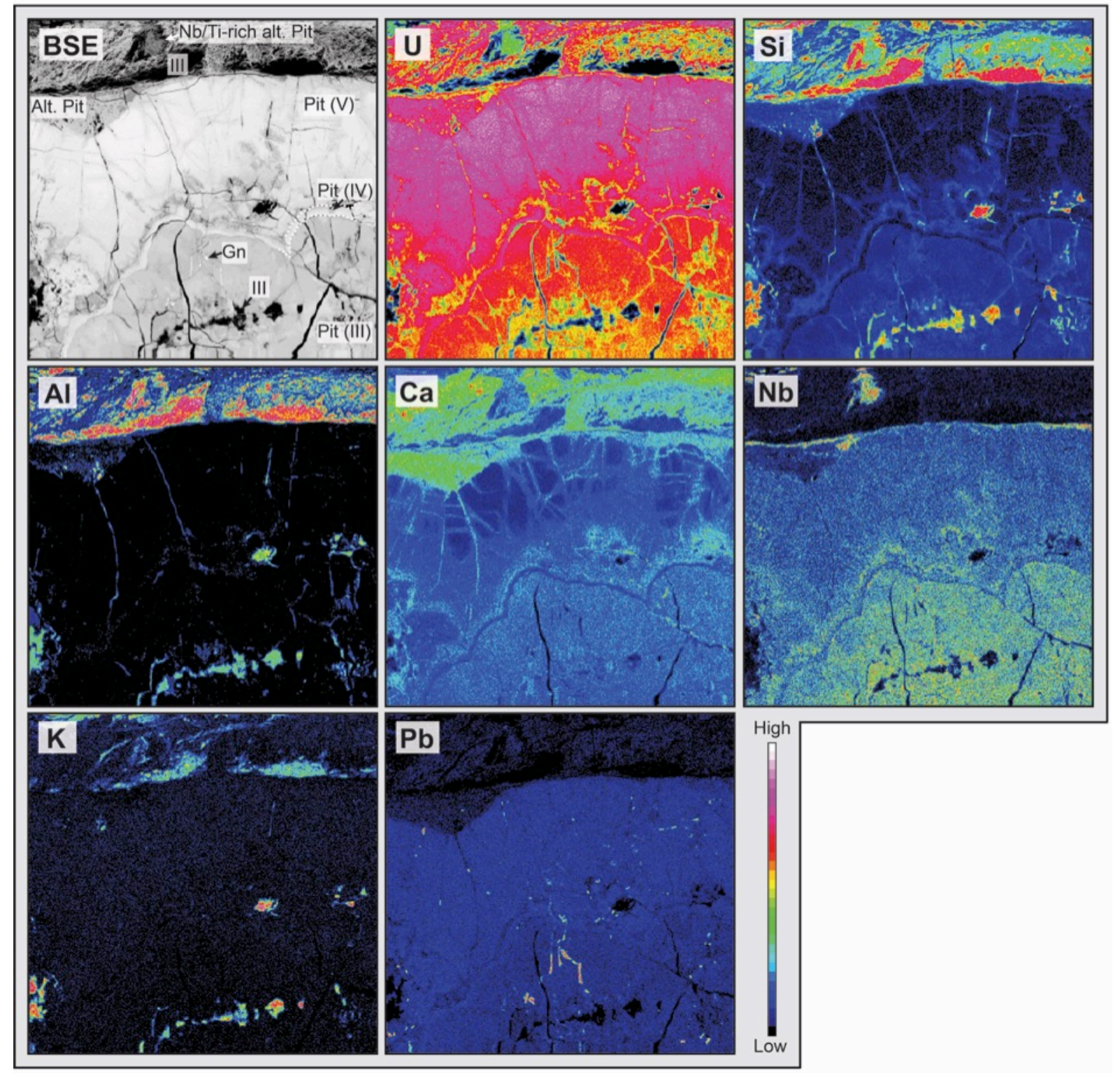

Figure 5, EPMA X-ray maps of pitchblende (III) to (V) and associated hydrothermal minerals characterising the primary $\mathrm{U}$ mineralisation in sample 5828 from the Baiyanghe deposit. Alt. = altered; $\mathrm{Gn}=$ galena; $\mathrm{Ill}=$ illite; Pit $=$ pitchblende. The white dashed lines show the boundaries between the different pitchblende growth bands. 


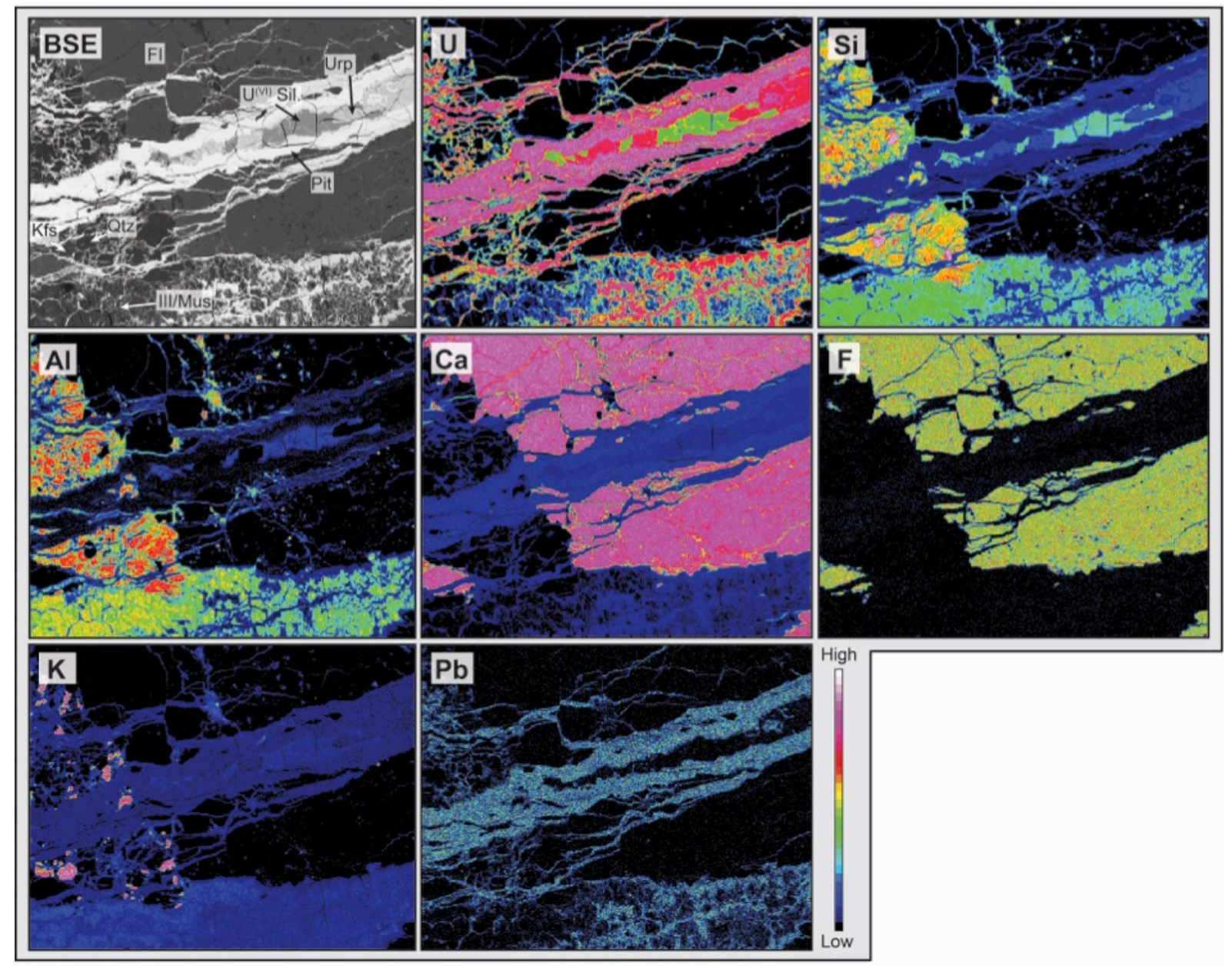

Figure 6, EPMA X-ray maps of pitchblende-hexavalent $U$ silicate-uranophane vein crosscutting Be ore-stage fluorite vein in sample 5434 from the Baiyanghe deposit. $\mathrm{U}^{(\mathrm{VI})}$ Sil. = hexavalent $\mathrm{U}$ silicate; $\mathrm{Fl}$ = fluorite; $\mathrm{Ill}=$ illite; $\mathrm{Kfs}=\mathrm{K}$-feldspar; Mus = muscovite; Pit = pitchblende; $\mathrm{Qtz}=$ quartz; Urp = uranophane. 

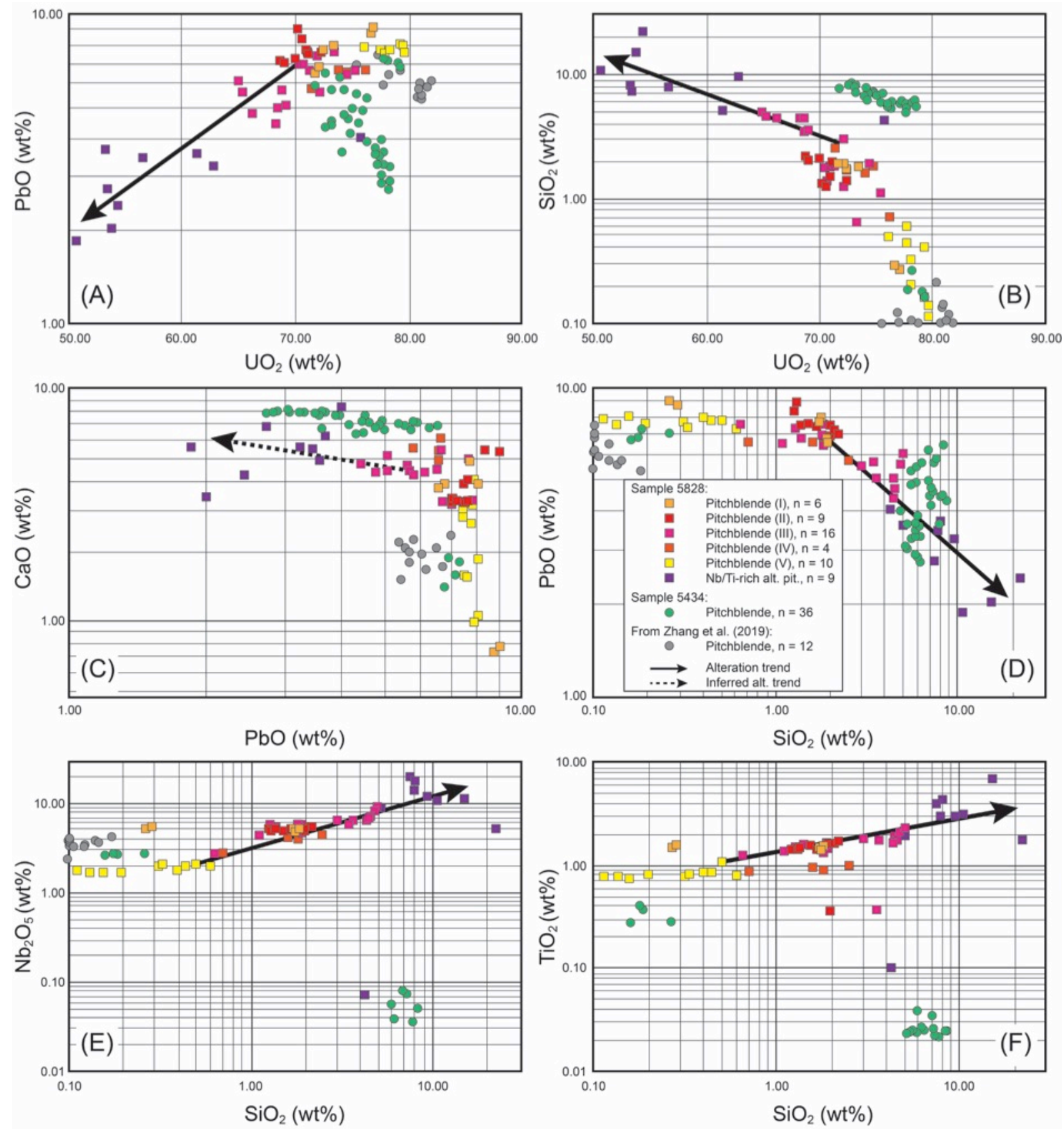

Figure 7, (A-F) Diagrams of major and minor elements displaying the chemical composition of pitchblende and $\mathrm{Nb} / \mathrm{Ti}$-rich altered pitchblende from the Baiyanghe deposit. Grey-filled cirlces indicate pitchblende composition from Zhang et al. (2019). 

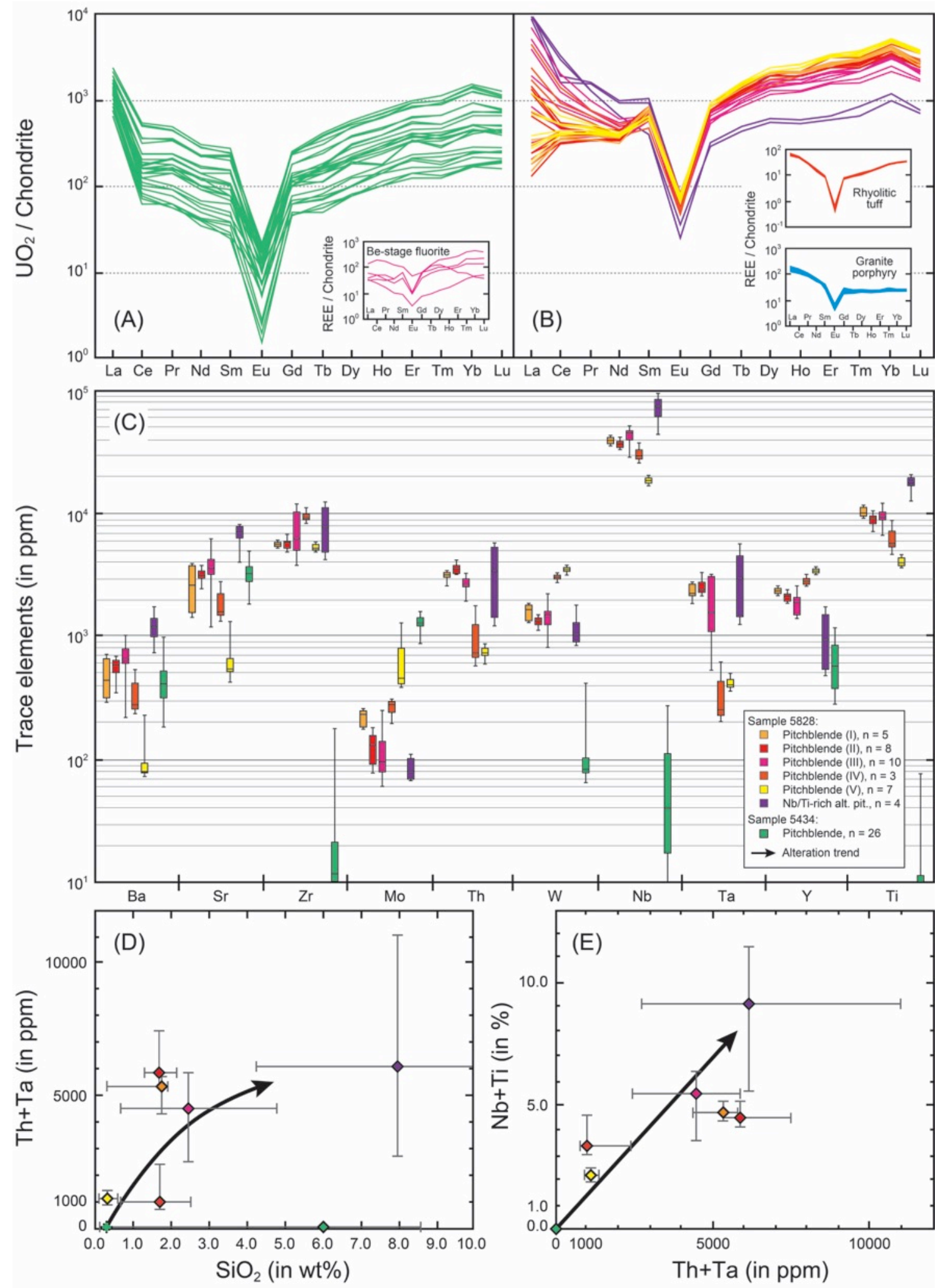

Figure 8, Chondrite-normalised REE patterns for pitchblende in samples 5434 (A) and 5828 (B) from the Baiyanghe deposit (Chondrite composition is from Taylor and McLennan (1985). Chondritenormalised REE patterns of the Yangzhuang granite porphyry, the rhyolitic tuff and Be-ore-stage dark purple fluorite from Zhang et al. (2019) are indicated for comparison; (C) Box plot diagram displaying the trace element signatures of pitchblende and $\mathrm{Nb}$ /Ti-rich altered pitchblende from the Baiyanghe deposit; (D and E) Th+Ta versus $\mathrm{SiO}_{2}$ and $\mathrm{Nb}+\mathrm{Ti}$ versus $\mathrm{Th}+\mathrm{Ta}$ diagrams showing pitchblende postcrystallisation features. 
data point error ellipses are $2 \sigma$
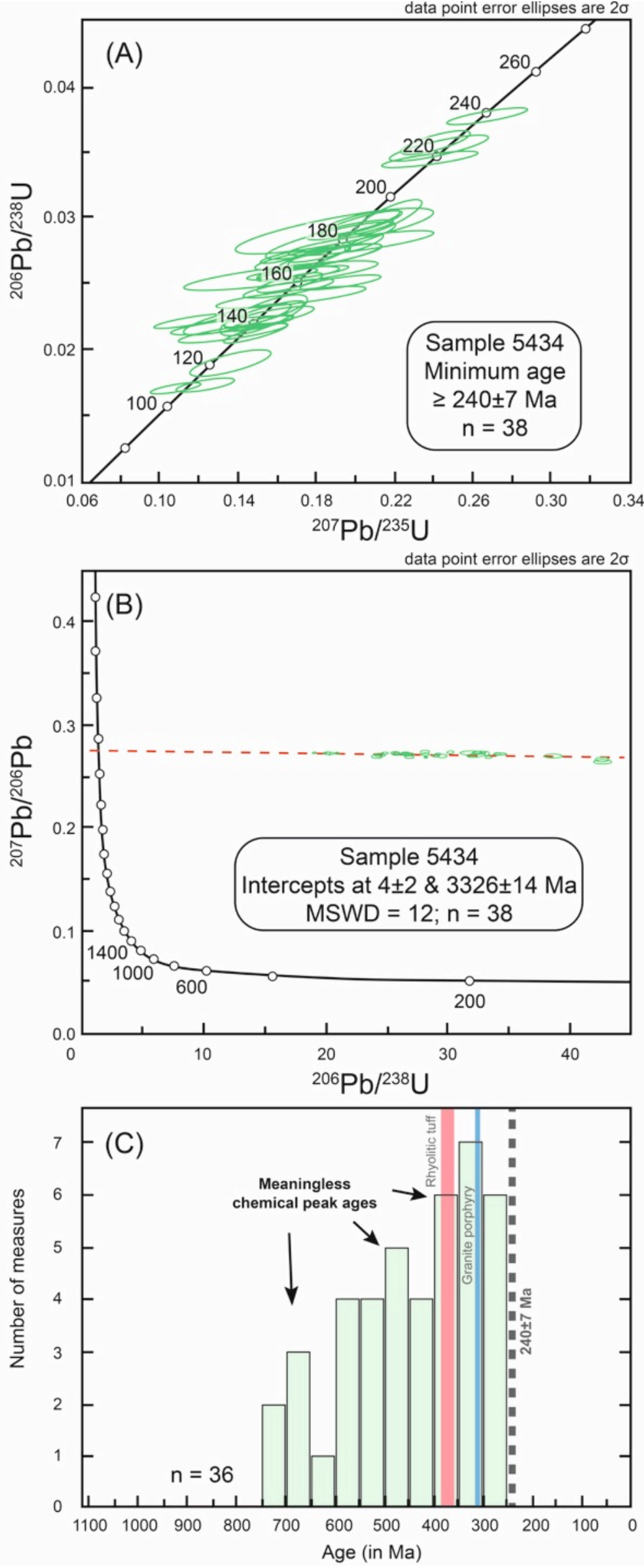
Figure 9, (A) Wetherill concordia plots of $\mathrm{U}-\mathrm{Pb}$ data corrected from common lead contamination for pitchblende in sample 5434 from the Baiyanghe deposit. The data error ellipses are at $2 \sigma$. Age given is the maximal ${ }^{207} \mathrm{~Pb} /{ }^{235} \mathrm{U}$ individual age (see Results); (B) Terra-Wasserburg concordia plots of U-Pb and $\mathrm{Pb}-\mathrm{Pb}$ data uncorrected from common lead contribution; (C) Histogram of U-Th-Pb chemical ages on pitchblende (calculated according to Bowles, 1990). The dashed line indicates the minimum crystallisation age of pitchblende and the thickness is representative of the error. 


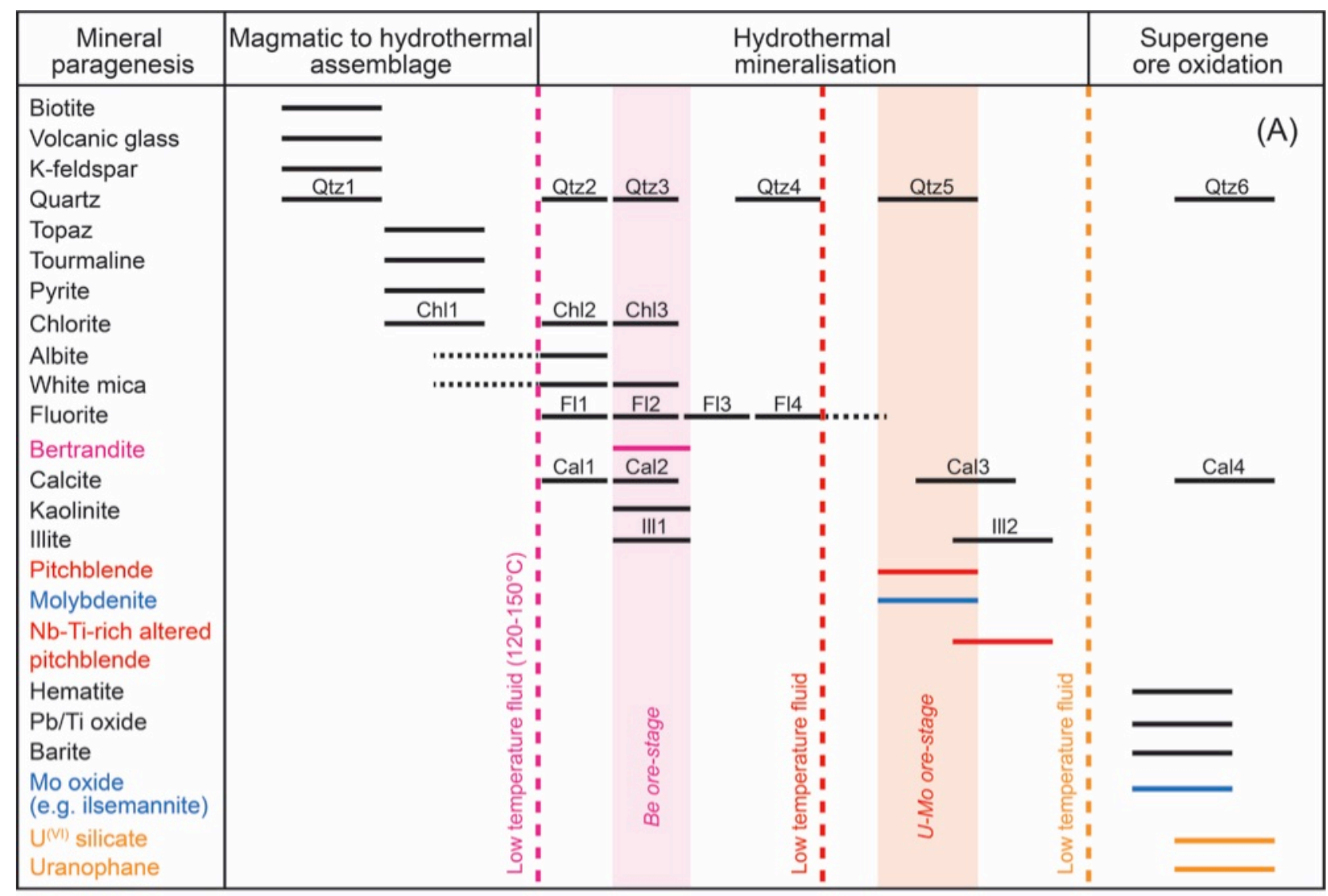

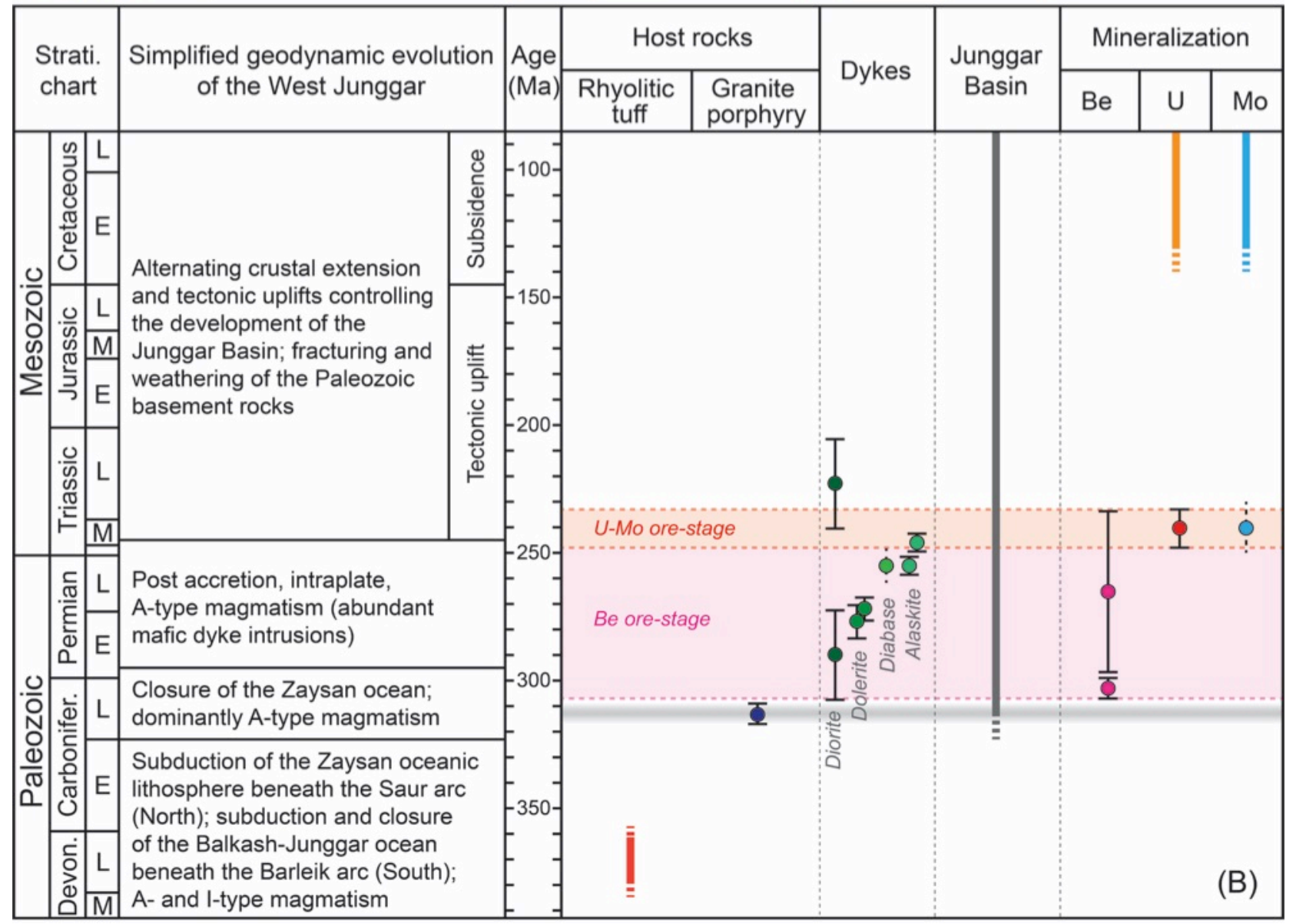


Figure 10, (A) Mineral succession diagram and metallogenic model related to the Be-U-Mo ore formation of the Baiyanghe deposit (modified from Fayek and Shabaga, 2011; Li et al., 2015; Zhang et al). $\mathrm{Cal}=$ calcite; $\mathrm{Chl}=$ chlorite; $\mathrm{Fl}=$ fluorite; $\mathrm{Ill}=$ illite; $\mathrm{Qtz}=$ quartz; (B) Regional geodynamicmetallogenic evolution of the Xuemisitan Volcanic Belt in northwest China during the emplacement of the late Devonian rhyolitic tuff and late Carboniferous Yangzhuang granite porphyry, and the BeU-Mo ore formation in the Baiyanghe deposit. Stratigraphic chart is after ICS (2016). Information regarding the major geodynamic events related to Be-U-Mo mineralisation that occurred during Paleozoic-Mesozoic in West Junggar is after Choulet et al. (2012, 2011), Li et al. (2015); Mao et al. (2014), Wang et al. (2019), and Zhang et al. (2019). U-Pb age of zircon from the Yangzhuang granite porphyry is from Zhang and Zhang (2014). Ages of mafic dykes are from Miao et al. (2019) and Yi et al. (2014). Ar-Ar age of Be-ore-stage hydrothermal muscovite is from Li et al. (2015). Sm-Nd age of Be-ore-stage dark purple fluorite is from $\mathrm{Yi}$ et al. (2016). U-Pb age of pitchblende is from this study and $\mathrm{U}-\mathrm{Pb}$ ages of uranophane are from Shabaga et al. (2015). E. = early, M. = middle, L. = late, Strati. $=$ stratigraphic. 


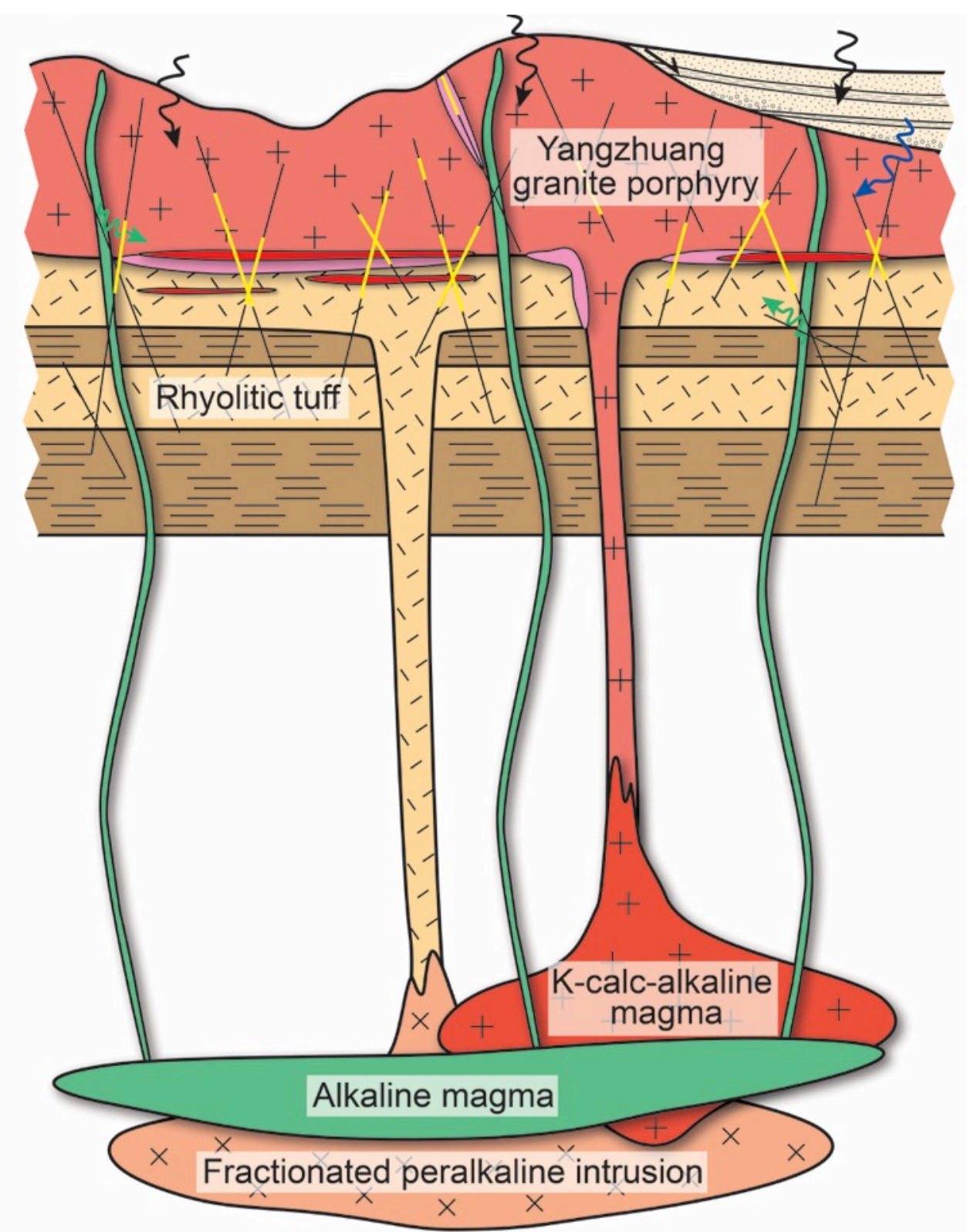

Late Carboniferous to Cenozoic

$\because \because \because$ Sedimentary cover

Late Carboniferous to late Triassic

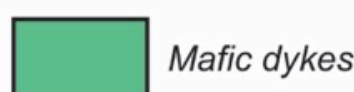

Late Carboniferous

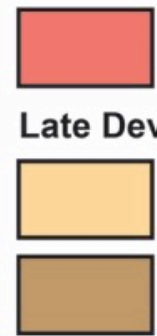

Granite prophyry

Rhyolitic tuff

Volcano-

sedimentary units
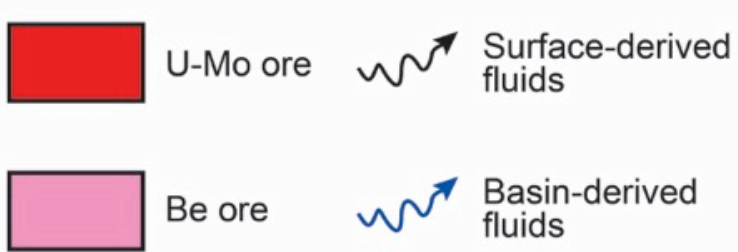

Be ore $\quad \sim 7$ Basin-derived fluids

— Fracture w w $\begin{aligned} & \text { Dyke-derived } \\ & \text { fluids }\end{aligned}$

Secondary

U ore 
Figure 11, Schematic model sections representing the genetic conditions of the volcanic-related hydrothermal Be-U-Mo mineralisation in the Baiyanghe deposit (modified after Fayek and Shabaga, 2011; Shabaga et al., 2015, 2013; Xu et al., 2017; Zhang et al., 2019).

\section{Electronic Supplementary Figure:}

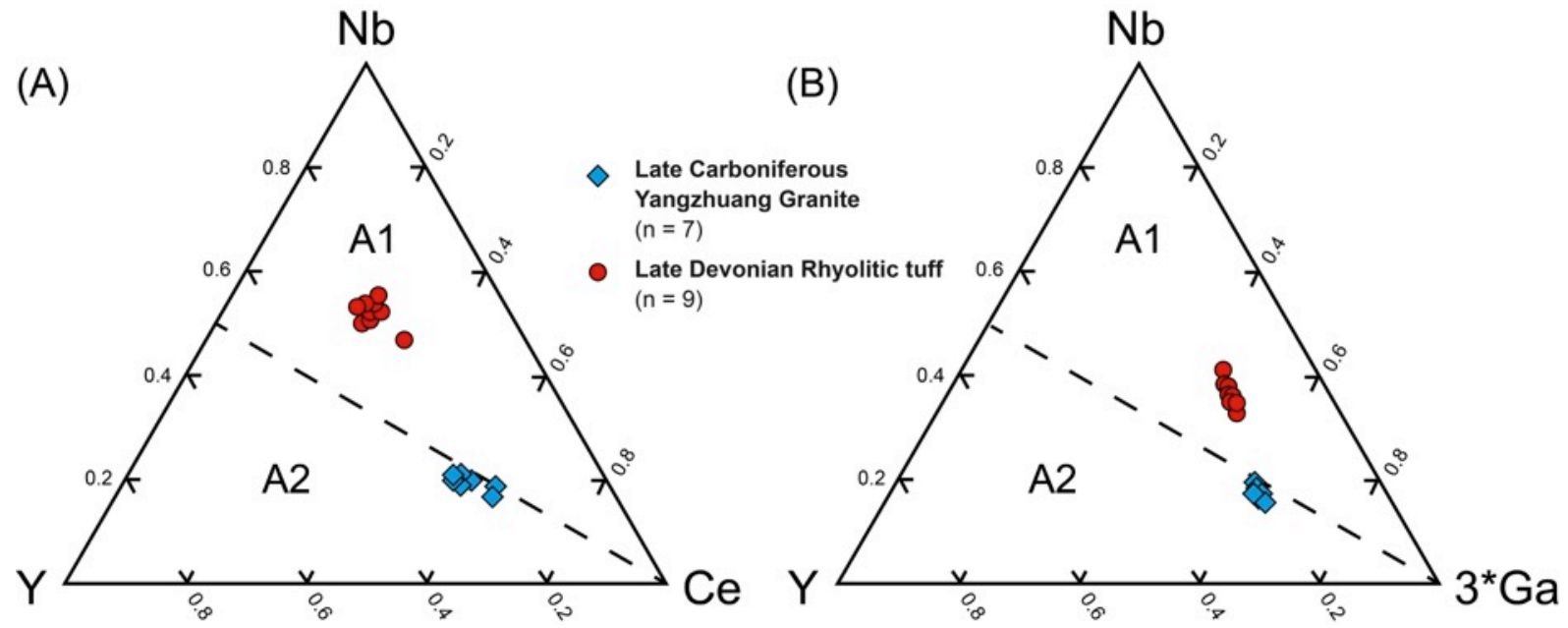

Figure A, Nb-Y-Ce and $\mathrm{Nb}-\mathrm{Y}-3 * \mathrm{Ga}$ diagrams (Eby, 1992) for classification of A-type magmatic rocks hosting Be-U-Mo mineralisation in the Baiyanghe deposit, Xuemisitan Volcanic Belt. 